\title{
Dopaminergic Modulation of Endocannabinoid-Mediated Plasticity at GABAergic Synapses in the Prefrontal Cortex
}

\author{
Chiayu Q. Chiu, ${ }^{1}$ Nagore Puente, ${ }^{2}$ Pedro Grandes, ${ }^{2}$ and Pablo E. Castillo ${ }^{1}$ \\ ${ }^{1}$ Dominick P. Purpura Department of Neuroscience, Albert Einstein College of Medicine, Bronx, New York 10461, and ${ }^{2}$ Department of Neurosciences, \\ Faculty of Medicine and Dentistry, Basque Country University, 699-48080 Bilbao, Spain
}

\begin{abstract}
Similar to dopamine (DA), cannabinoids strongly influence prefrontal cortical functions, such as working memory, emotional learning, and sensory perception. Although endogenous cannabinoid receptors $\left(\mathrm{CB}_{1} \mathrm{Rs}\right)$ are abundantly expressed in the prefrontal cortex (PFC), very little is known about endocannabinoid (eCB) signaling in this brain region. Recent behavioral and electrophysiological evidence has suggested a functional interplay between the dopamine and cannabinoid receptor systems, although the cellular mechanisms underlying this interaction remain to be elucidated. We examined this issue by combining neuroanatomical and electrophysiological techniques in PFC of rats and mice (both genders). Using immunoelectron microscopy, we show that $C_{1} R s$ and dopamine type 2 receptors $\left(D_{2} R s\right)$ colocalize at terminals of symmetrical, presumably GABAergic, synapses in the PFC. Indeed, activation of either receptor can suppress GABA release onto layer 5 pyramidal cells. Furthermore, coactivation of both receptors via repetitive afferent stimulation triggers eCB-mediated long-term depression of inhibitory transmission (I-LTD). This I-LTD is heterosynaptic in nature, requiring glutamate release to activate group I metabotropic glutamate receptors. $\mathrm{D}_{2} \mathrm{Rs}$ most likely facilitate eCB signaling at the presynaptic site as disrupting postsynaptic $\mathrm{D}_{2} \mathrm{R}$ signaling does not diminish I-LTD. Facilitation of eCB-LTD may be one mechanism by which DA modulates neuronal activity in the PFC and regulates PFC-mediated behavior in vivo.
\end{abstract}

\section{Introduction}

Dopaminergic innervation of the prefrontal cortex (PFC) strongly modulates high-level cognitive processes (Le Moal and Simon, 1991; Goldman-Rakic, 1998; Seamans and Yang, 2004). Unlike fast ionotropic neurotransmitters, dopamine (DA) does not directly mediate synaptic transmission but affects it by altering the cellular or synaptic properties of target neurons (Greengard, 2001; Seamans and Yang, 2004; Iversen and Iversen, 2007). The recent link between DA and endocannabinoids (eCBs) (van der Stelt and Di Marzo, 2003; Laviolette and Grace, 2006) is particularly interesting in the PFC given the well known hallucinogenic effects of exogenous cannabinoids and the potential eCB association with neuropsychiatric disorders that reflect PFC dysfunction (Ujike and Morita, 2004; Koethe et al., 2009; Sewell et al., 2009). However, it remains unclear exactly how eCBs regulate PFC function and whether DA plays a role in this regulation.

\footnotetext{
Received Feb. 10, 2010; revised April 2, 2010; accepted April 15, 2010.

Funding for P.E.C.'s laboratory is provided by National Institutes of Health/National Institute on Drug Abuse and by National Alliance for Research on Schizophrenia and Depression. Funding for P.G.'s laboratory is provided by The Basque Country Government Grant GIC07/70-IT-432-07 and by Red de Trastornos Adictivos, Redes Teméticas de Investigación Cooperativa en Salud, Instituto de Salud Carlos III, Ministerio de Ciencia e Innovación Grant RD07/ 0001/2001. N.P. is supported by The Basque Country University grant for PhD Researcher's Specialization. We especially thank Dr. Andrés Chávez for his work that forms the basis for Figure $6 B$ and Drs. Wade Regehr, David Lovinger, and Giovanni Marsicano for providing $\mathrm{CB}_{1}$ knock-out mice. We also thank all members of the Castillo Laboratory for critical reading of this manuscript.

Correspondence should be addressed to Pablo E. Castillo, Dominick P. Purpura Department of Neuroscience, Albert Einstein College of Medicine, Rose F. Kennedy Center,1410 Pelham Parkway South, Room 701, Bronx, NY 10461. E-mail: pablo.castillo@einstein.yu.edu.

DOI:10.1523/JNEUROSCI.0736-10.2010
}

Copyright $\odot 2010$ the authors $\quad 0270-6474 / 10 / 307236-13 \$ 15.00 / 0$
Short- and long-term synaptic plasticity mediated by eCBs has been reported in several brain regions (for recent reviews, see Chevaleyre et al., 2006; Lovinger, 2008; Heifets and Castillo, 2009; Kano et al., 2009). Recent evidence in the midbrain suggests that $D A$, via $\mathrm{D}_{2}$-like receptors $\left(\mathrm{D}_{2} \mathrm{Rs}\right)$, can facilitate $\mathrm{eCB}$ signaling and eCB-mediated plasticity (Melis et al., 2004; Kreitzer and Malenka, 2005; Yin and Lovinger, 2006; Kreitzer and Malenka, 2007; Shen et al., 2008). Consistent with the observation that $\mathrm{D}_{2} \mathrm{R}$ activation increases striatal levels of the $\mathrm{eCB}$ anandamide in vivo (Giuffrida et al., 1999), it was suggested that DA acts via postsynaptic $\mathrm{D}_{2} \mathrm{Rs}$ by promoting the production of eCBs. However, like $\mathrm{CB}_{1} \mathrm{Rs}, \mathrm{D}_{2}$ Rs are coupled to $\mathrm{G}_{\mathrm{i} / \mathrm{o}}$-proteins and their activation leads to the inhibition of adenylyl cyclase (AC), resulting in a reduction of cAMP levels and protein kinase A (PKA) activity. The observation that $\mathrm{D}_{2}$ Rs may be present at presynaptic locations in the PFC (Fadda et al., 1984; Seamans et al., 2001) raises the possibility that $\mathrm{CB}_{1}$ Rs and $\mathrm{D}_{2}$ Rs may colocalize on the same axon terminals and perhaps be coactivated by physiological synaptic activity. It is unknown how coincident activation of presynaptic $\mathrm{CB}_{1}$ Rs and $\mathrm{D}_{2} \mathrm{Rs}$ in the PFC may affect transmitter release.

Most studies on eCB-mediated plasticity have concentrated on excitatory synapses, and the PFC is no exception. Pharmacological activation of $\mathrm{CB}_{1}$ Rs suppresses excitatory inputs to layer 5 pyramidal cells in rodent PFC (Auclair et al., 2000; Lafourcade et al., 2007), and repetitive stimulation in PFC can elicit long-term depression of excitatory transmission (E-LTD) (Lafourcade et al., 2007). However, given that a balance of excitation and inhibition shapes neuronal excitability and network firing patterns, knowledge of how eCBs influence inhibitory transmission in the PFC will be necessary to predict the functional impact of $\mathrm{eCB}$ signaling 
in this structure. Here, we investigate eCB signaling at inhibitory synapses in the PFC and demonstrate facilitation of inhibitory LTD (I-LTD) by the dopaminergic system. Our findings suggest a potential synaptic link between $\mathrm{ECB}$ and DA function in the PFC. Dysregulation of this crosstalk may play a role in neuropsychiatric disorders, such as schizophrenia.

\section{Materials and Methods}

Double $C B_{1} R / D_{2} R$ immunocytochemistry for electron microscopy. Female mice ( $n=3,2$ months old, C57BL/6 strain) were deeply anesthetized with chloral hydrate ( $400 \mathrm{mg} / \mathrm{kg}$ body weight). $C B_{1} R^{-1-}$ knock-out mice ( $n=2$; kindly provided by Dr. Giovanni Marsicano, Institute François Magendie, Bordeaux, France) (Marsicano et al., 2002) were used as controls of $\mathrm{CB}_{1} \mathrm{R}$ antibody specificity. All animals were transcardially perfused with phosphate-buffered solution (PB) $(0.1 \mathrm{M}, \mathrm{pH} 7.4)$ and then fixed by $500 \mathrm{ml}$ of $0.1 \%$ glutaraldehyde, $4 \%$ formaldehyde (freshly depolymerized from paraformaldehyde), and $0.2 \%$ picric acid in $0.1 \mathrm{M} \mathrm{PB}, \mathrm{pH}$ 7.4, prepared at $4^{\circ} \mathrm{C}$. Tissue blocks were extensively rinsed in $0.1 \mathrm{M} \mathrm{PB}$, $\mathrm{pH}$ 7.4. Rostral vibrosections containing the PFC were cut at $50 \mu \mathrm{m}$ and collected in $0.1 \mathrm{M} \mathrm{PB}, \mathrm{pH} 7.4$, at room temperature (RT). Sections were preincubated in a blocking solution of $10 \%$ bovine serum albumin (BSA), $0.1 \%$ sodium azide, and $0.02 \%$ saponin prepared in Tris- $\mathrm{HCl}-$ buffered saline (TBS), pH 7.4, for 30 min at RT.

A preembedding silver-intensified immunogold method and an immunoperoxidase method were used for the colocalization of $\mathrm{CB}_{1} \mathrm{R}$ and $\mathrm{D}_{2} \mathrm{R}$ in mouse PFC sections. Two primary polyclonal antibodies were used in this study: goat $\mathrm{CB}_{1} \mathrm{R}$ raised against a 31 aa $\mathrm{C}$-terminal sequence (GenBank accession number NM007726) of the mouse $\mathrm{CB}_{1} \mathrm{R}$ (CB1-GoAf450-1; Frontier Science) and rabbit $\mathrm{D}_{2} \mathrm{R}$ raised against a 28 aa sequence (amino acids 284-311) within the third cytoplasmic loop of the human $\mathrm{D}_{2} \mathrm{R}$, which is common to both long and short forms of the receptor (AB5084P; Millipore Bioscience Research Reagents). The $\mathrm{CB}_{1} \mathrm{R}(2 \mu \mathrm{g} /$ $\mathrm{ml})$ and $\mathrm{D}_{2} \mathrm{R}(5 \mu \mathrm{g} / \mathrm{ml})$ antibodies prepared in $10 \% \mathrm{BSA} / \mathrm{TBS}$ containing $0.1 \%$ sodium azide and $0.004 \%$ saponin were incubated simultaneously in PFC tissue on a shaker for $2 \mathrm{~d}$ at $4^{\circ} \mathrm{C}$.

After several washes in $1 \%$ BSA/TBS, sections were incubated in a secondary $1.4 \mathrm{~nm}$ gold-labeled rabbit anti-goat IgG (Fab' fragment, $1: 100$; Nanoprobes) for the detection of $\mathrm{CB}_{1} \mathrm{R}$ and in a biotinylated donkey anti-rabbit IgG (1:200; Jackson ImmunoResearch) for the detection of $\mathrm{D}_{2} \mathrm{R}$, in both $1 \% \mathrm{BSA} / \mathrm{TBS}$ with $0.004 \%$ saponin on a shaker for $4 \mathrm{~h}$ at RT. PFC tissue was washed in $1 \%$ BSA/TBS and processed by a conventional avidin-biotin horseradish peroxidase complex method (ABC Elite; Vector Laboratories). The sections were washed in 1\% BSA/TBS overnight at $4^{\circ} \mathrm{C}$ and postfixed in $1 \%$ glutaraldehyde in TBS for $10 \mathrm{~min}$ at RT. After washes in double-distilled water, gold particles were silver intensified with an HQ Silver kit (Nanoprobes) for $\sim 12$ min in the dark and then washed in $0.1 \mathrm{M} \mathrm{PB}, \mathrm{pH}$ 7.4. The tissue was preincubated subsequently with $0.05 \% \mathrm{DAB}$ in $0.1 \mathrm{M} \mathrm{PB}$ for $5 \mathrm{~min}$, incubated by adding $0.01 \%$ hydrogen peroxide to the same solution for $5 \mathrm{~min}$, and washed in $0.1 \mathrm{M}$ PB for $2 \mathrm{~h}$ at RT. Stained sections were osmicated $\left(1 \% \mathrm{OsO}_{4}\right.$ in $0.1 \mathrm{M}$ $\mathrm{PB}, \mathrm{pH}$ 7.4, $20 \mathrm{~min}$ ), dehydrated in graded alcohols to propylene oxide, and plastic-embedded flat in Epon 812. Ultrathin sections $(80 \mathrm{~nm})$ were collected on mesh nickel grids, stained with lead citrate, and examined in a Philips EM2008S electron microscope. Tissue preparations were photographed by using a digital camera coupled to the electron microscope.

Specificity of the immunostainings was assessed as follows: $\mathrm{CB}_{1} \mathrm{R}$ antibodies were incubated in $C B_{1} R^{-/-}$PFC tissue in the same conditions as above. In this case, $\mathrm{CB}_{1} \mathrm{R}$ immunolabeling was not observed in cortical synapses of $\mathrm{CB}_{1} \mathrm{R}$ deficient mice (data not shown). The $\mathrm{D}_{2} \mathrm{R}$ antibodies gave a similar faint cortical pattern as described in the light microscopy in previous publications using the same antiserum (Wang and Pickel, 2002; Lei et al., 2004). In addition, no specific staining was detected in sections in which the primary $\mathrm{D}_{2} \mathrm{R}$ antibodies were replaced by goat serum (data not shown). Figure compositions were scanned at 300 dots per inch. Labeling and minor adjustments in contrast and brightness were made using Adobe Photoshop (CS; Adobe Systems).

Quantitative analysis of electron microscopy images. The quantitative analysis was made in layer $5 / 6$ of PFC sections obtained from three mice processed for $\mathrm{CB}_{1} \mathrm{R} / \mathrm{D}_{2} \mathrm{R}$ colocalization with preembedding immunocytochemistry. PFC sections, $50 \mu \mathrm{m}$ thick, from each animal showing good and reproducible $\mathrm{DAB}$ immunoreaction $\left(\mathrm{D}_{2} \mathrm{R}\right)$ and silver-intensified gold particles $\left(\mathrm{CB}_{1} \mathrm{R}\right)$ were cut at $80 \mathrm{~nm}$. Electron micrographs $(18,000-$ $28,000 \times$ ) were taken from grids ( $132 \mu \mathrm{m}$ side) containing DAB immunodeposits; all ultrathin sections showed a similar DAB labeling intensity, indicating that selected areas were at the same depth. Positive $\mathrm{CB}_{1} \mathrm{R}$ labeling was determined by observation of at least one immunoparticle within $\sim 30 \mathrm{~nm}$ of the plasmalemma of axon terminals forming symmetrical-type synapses. Presynaptic boutons with $\mathrm{D}_{2} \mathrm{R}$ immunodeposits making symmetrical synapses were also counted. Percentages of presynaptic inhibitory-like profiles positive for $\mathrm{CB}_{1} \mathrm{R}$ or $\mathrm{D}_{2} \mathrm{R}$ were analyzed and displayed using a statistical software package (GraphPad Prism 4; GraphPad Software). Finally, the percentage of $\mathrm{CB}_{1} \mathrm{R}$ positive terminals at symmetrical synapses that colocalize with $D_{2} R$ as well as the percentage of immunoreactive $\mathrm{D}_{2} \mathrm{R}$ axonal boutons with $\mathrm{CB}_{1} \mathrm{R}$ immunolabeling that form symmetrical synapses were also analyzed. Data are presented as mean \pm SEM. A total of 250 inhibitorylike presynaptic axon terminals in an area of $642.492 \mu \mathrm{m}^{2}$ were measured and analyzed by NIH ImageJ (version 1.36).

Electrophysiological recordings. All animal experiments were performed in accordance with the National Institutes of Health Guide for the Care and Use of Laboratory Animals. Acute prefrontal cortical slices were prepared from postnatal day 16 (P16) to P25 Wistar rats and P24-P46 C57BL/6 mice from Charles River Laboratories or from our colony of Zimmer line $C B_{1} R^{-/-}$mice (Zimmer et al., 1999). The $C B_{1} R^{-/-}$mouse colony was maintained as heterozygotes and genotyped before use as described previously (Takahashi and Castillo, 2006). Male and female animals were anesthetized with isoflurane and decapitated, and their brains were removed to a chilled cutting solution consisting of the following (in mM): 215 sucrose, $2.5 \mathrm{KCl}, 26 \mathrm{NaHCO}_{3}, 1.6 \mathrm{NaH}_{2} \mathrm{PO}_{4}, 1$ $\mathrm{CaCl}_{2}, 4 \mathrm{MgCl}_{2}, 4 \mathrm{MgSO}_{4}$, and 20 glucose. The posterior end of the brain was truncated flat with a razor blade, and then the brain was positioned in the cutting chamber with the cut end on the bottom. Coronal slices (350 $\mu \mathrm{m}$ thick) were cut with a DTK-2000 (Dosaka) or Leica VT1200 S (Leica Microsystems) vibrating microslicer. Rostral sections containing the prelimbic-infralimbic region of the PFC were stored at room temperature in holding solution containing the following (in $\mathrm{mm}$ ): $63 \mathrm{NaCl}, 2.5 \mathrm{KCl}, 22$ $\mathrm{NaHCO}_{3}, 1.4 \mathrm{NaH}_{2} \mathrm{PO}_{4}, 1.1 \mathrm{CaCl}_{2}, 3.2 \mathrm{MgCl}_{2}, 2 \mathrm{MgSO}_{4}, 15.5$ glucose, and 107.5 sucrose. Thirty minutes after sectioning, slices were placed in extracellular recording solution containing the following (in $\mathrm{mM}$ ): 126 $\mathrm{NaCl}, 2.5 \mathrm{KCl}, 18 \mathrm{NaHCO}_{3}, 1.2 \mathrm{NaH}_{2} \mathrm{PO}_{4}, 1.2 \mathrm{CaCl}_{2}, 2.4 \mathrm{MgCl}_{2}$, and 11 glucose. All solutions were saturated with $95 \% \mathrm{O}_{2}$ and $5 \% \mathrm{CO}_{2}$, pH 7.4. Slices were incubated for at least $30 \mathrm{~min}$ in the recording solution before experiments.

All experiments were conducted in a submersion-type recording chamber perfused at $\sim 2 \mathrm{ml} / \mathrm{min}$, and the recording temperature was maintained at $30 \pm 1^{\circ} \mathrm{C}$ using a TC-344B dual-channel heater controller (Warner Instruments). Whole-cell patch-clamp experiments were performed in $10 \mu \mathrm{M}$ 2,3-dioxo-6-nitro-1,2,3,4-tetrahydrobenzo[f] quinoxaline7-sulfonamide (NBQX) or CNQX (AMPAR/kainate receptor antagonists) and $25 \mu \mathrm{M}$ APV (NMDAR antagonist). In recordings of miniature IPSCs (mIPSCs), $1 \mu \mathrm{M}$ tetrodotoxin was additionally applied in the bath. To record $\mathrm{GABA}_{\mathrm{A}} \mathrm{R}$-mediated IPSCs, layer 5 pyramidal cells were voltage clamped at 0 $\mathrm{mV}$ using patch-type pipettes filled with intracellular solution containing the following (in mM): 131 Cs-gluconate, $8 \mathrm{NaCl}, 1 \mathrm{CaCl}_{2}, 10 \mathrm{EGTA}, 10$ glucose, 10 HEPES, $5 \mathrm{MgATP}$, and $0.4 \mathrm{Na}_{3} \mathrm{GTP}$, pH $7.2(285 \mathrm{mmol} / \mathrm{kg})$. In experiments with postsynaptic calcium chelators, $20 \mathrm{~mm}$ Cs and $10 \mathrm{~mm}$ EGTA was replaced with 20 mM BAPTA. In some experiments, we assessed the electrophysiological properties of the patched pyramidal cells using a K-based internal solution containing the following (in $\mathrm{mm}$ ): $130 \mathrm{~K}$-gluconate, $10 \mathrm{NaCl}$, 0.2 EGTA, 10 HEPES, 5 MgATP, and $0.4 \mathrm{Na}_{3} \mathrm{GTP}$, pH $7.2(285 \mathrm{mmol} / \mathrm{kg})$. Series resistance (typically 5-15 M $\Omega$ ) was monitored throughout the experiment with a $-4 \mathrm{mV}, 80 \mathrm{~ms}$ voltage step, and recordings with a $>10 \%$ change in series resistance were excluded from analysis.

Stimulating electrodes were filled with extracellular recording solution and placed in layer $2 / 3$ to stimulate distal inhibitory inputs and layer 5 to stimulate proximal inhibitory inputs. Patched cells were typically no more than $50 \mu \mathrm{m}$ lateral from the tips of stimulating electrodes. Each 
pathway was stimulated every $20 \mathrm{~s}$, and synaptic responses typically ranged from 200 to $800 \mathrm{pA}$. I-LTD in the rat was triggered in layer $2 / 3$ inputs by a $5 \mathrm{~Hz}$ train of synaptic stimulation lasting $10 \mathrm{~min}$, at twice the test stimulus intensity. In the mouse PFC, a shorter $5 \mathrm{~Hz}$ train ( $5 \mathrm{~min}$ ) was required to induce I-LTD. Stimulation was triggered by a Master- 8 pulse generator (A.M.P.I.), and acquisition was controlled by customwritten software in Igor Pro 4.09A (Wavemetrics). Whole-cell patchclamp recordings were performed using a Multiclamp 700B amplifier (Molecular Devices).

To assess the efficacy of loading protein kinase A inhibitor (PKI) 6-22 peptide in the patch pipette to inhibit postsynaptic PKA activity, experiments were performed in the CA1 region to monitor slow afterhyperpolarization potential currents $\left(I_{\mathrm{AHP}}\right)$, which is modulated by PKA activation (Pedarzani and Storm, 1993). Transverse hippocampal slices $(400 \mu \mathrm{m})$ were prepared from P23-P25 Wistar rats. Slow $I_{\mathrm{AHP}}$ were elicited by a depolarizing step (between 60 and $70 \mathrm{mV}$ ) for $100 \mathrm{~ms}$ in CA1 pyramidal cells voltage clamped between -50 to $-55 \mathrm{mV}$ with intracellular solution containing the following (in mM): $120 \mathrm{~K}$-gluconate, 20 $\mathrm{KCl}, 15 \mathrm{HEPES}, 2 \mathrm{Mg}$-ATP, $0.2 \mathrm{GTP}, 1 \mathrm{MgCl}_{2}$, and 0.1 EGTA. Sp-cAMPS at $50 \mu \mathrm{M}$ was used to inhibit the slow $I_{\mathrm{AHP}}$ component, and the $I_{\mathrm{AHP}}$ amplitude was measured 15-20 min after Sp-cAMPS application under control conditions or in cells loaded with 2.5 or $100 \mu \mathrm{M}$ PKI 6-22.

Quantitative analysis of electrophysiological data. All values are provided as mean \pm SEM. The paired-pulse ratio (PPR) was defined as the ratio of the amplitude of the second IPSC over the amplitude of the first IPSC. The magnitude of drug effects was calculated as the percentage change between baseline (averaged responses for the $10 \mathrm{~min}$ before drug application) and 20-30 min after start of WIN 55,212-2 (WIN) $[R-(+)-$ [2,3-dihydro-5-methyl-3-(4-morpholinylmethyl)pyrrolo[1,2,3-de]1,4-benzoxazin-6-yl]-1-naphthalenyl methanone mesylate] or H89 ( $\mathrm{N}$-[2-[[3-(4-bromophenyl)-2-propenyl]amino] ethyl]-5-isoquinolinesulfonamide dihydrochloride) application, 10-15 min after start of quinpirole application or 20-30 min after the start of bromocriptine application. The magnitude of I-LTD was calculated as the percentage change between baseline and 20-30 min after complete delivery of tetanus. Statistical analysis was performed using Student's independent $t$ test at the $p<0.05$ significance level in OriginPro 7.0 software (OriginLab Corp), unless otherwise stated.

Drugs. WIN 55,212-2, (-)-quinpirole hydrochloride, bromocriptine mesylate, $(S)-(-)$-sulpiride, SCH23390 $[R(+)$-7-chloro-8-hydroxy-3methyl-1-phenyl-2,3,4,5-tetrahydro-1 H-3-benzazepine] hydrochloride, LY367385 [( S)-(+)- $\alpha$-amino-4-carboxy-2-methylbenzeneacetic acid], OR 486 (3,5-dinitrocatechol), and picrotoxin were purchased from Tocris Bioscience. PKI 6-22 and PKI 14-22 peptides were obtained from either Tocris Bioscience or BIOMOL Research Laboratories. SpcAMPS was acquired from BIOMOL Research Laboratories. D-APV, NBQX, CNQX, 2-methyl-6-(phenylethynyl)-pyridine (MPEP) hydrochloride, and AM 251 [N-(piperidin-1-yl)-1-(2,4- dichlorophenyl)-5(4-iodophenyl)-4-methyl- $1 \mathrm{H}$-pyrazole-3-carboxamide] were obtained from Ascent Scientific. H89 was procured from LC Labs. Total DMSO in the bath solution was maintained at $0.1 \%$ or below in all experiments.

\section{Results}

\section{Anatomical evidence for $\mathrm{CB}_{1} \mathrm{R}$ and $\mathrm{D}_{2} \mathrm{R}$ presynaptic colocalization in the mouse PFC}

We first assessed anatomically whether $\mathrm{CB}_{1} \mathrm{Rs}$ and $\mathrm{D}_{2}$ Rs colocalize at inhibitory synaptic terminals in the PFC. Double immunoelectron microscopy was used to precisely determine the localization of $\mathrm{CB}_{1}$ Rs and $\mathrm{D}_{2}$ Rs in layers $2 / 3$ (Fig. $1 A, B$ ) and 5/6 (Fig. $1 C-F$ ) of the mouse PFC. Immunoperoxidase labeling of $\mathrm{D}_{2} \mathrm{Rs}$ (thick arrows) and immunogold labeling of $\mathrm{CB}_{1} \mathrm{Rs}$ (thin arrows) was frequently observed within axonal profiles in both layers (Fig. $1 A-F)$, which formed symmetrical synapses onto small postsynaptic dendrites and somatic membranes. $\mathrm{CB}_{1} \mathrm{R}$ immunoparticles were consistently associated with portions of presynaptic membranes away from the active zones, as expected for its known perisynaptic localization. To assess the degree of colocalization between $\mathrm{CB}_{1}$ Rs and $\mathrm{D}_{2}$ Rs, quantitative measurements were performed in layer $5 / 6$ of PFC sections (Fig. 1G). Notably, $\sim 50 \%$ of relatively small presynaptic boutons with restricted immunoreaction for the $\mathrm{D}_{2} \mathrm{R}$ colocalized with $\mathrm{CB}_{1} \mathrm{R}$ immunoparticles along their membranes. A similarly high proportion of inhibitory presynaptic boutons with $\mathrm{CB}_{1} \mathrm{R}$ immunolabeling also contained $\mathrm{D}_{2} \mathrm{R}$ immunoreactivity. Although this number is probably an underestimation, $\sim 30 \%$ of presynaptic boutons with pleomorphic synaptic vesicles and symmetrical synapses were immunonegative for both $\mathrm{CB}_{1} \mathrm{R}$ and $\mathrm{D}_{2} \mathrm{R}$ in layers $5 / 6$. The high number of symmetrical synapses expressing either $\mathrm{CB}_{1} \mathrm{R}$ or $\mathrm{D}_{2} \mathrm{R}$ suggests that $\mathrm{eCBs}$ and $\mathrm{DA}$ play significant roles in modulating inhibitory transmission in the PFC. The superficial layer $2 / 3$ also exhibited the same pattern of $C B_{1} R / D_{2} R$ colocalization in presynaptic terminals impinging symmetrically on postsynaptic membranes of cell bodies and small-diameter dendrites (Fig. $1 A, B)$. Thus, our electron microscopy (EM) images reveal a strong pattern of colocalization between $\mathrm{CB}_{1}$ Rs and $\mathrm{D}_{2}$ Rs at terminals of symmetrical, presumably inhibitory, synapses in both layers $2 / 3$ and $5 / 6$ of the mouse PFC.

\section{Pharmacological activation of $C_{1}$ Rs or $D_{2}$ Rs suppresses GABAergic transmission in mouse and rat PFC, most likely via a presynaptic mechanism}

Because both $\mathrm{CB}_{1}$ Rs and $\mathrm{D}_{2}$ Rs are present at terminals of symmetrical presumably GABAergic synapses, we next tested whether activation of these receptors has any functional effect on GABAergic synaptic transmission. Whole-cell recordings of pharmacologically isolated IPSCs were obtained from layer 5 pyramidal cells in acute mouse PFC slices. The identity of pyramidal cells was confirmed by assessment of electrophysiological properties and pyramidal cell-like morphology under infrared-differential interference contrast (IR-DIC) microscopy (Fig. 2A). Exogenous bath application of the $\mathrm{CB}_{1} \mathrm{R}$ agonist WIN 55,212-2 (5 $\left.\mu \mathrm{M}\right)$ suppressed IPSCs evoked by focal stimulation via electrodes placed distally in layer $2 / 3$ as well as proximally in layer 5 (Fig. 2 B). IPSC amplitudes after WIN application were $49.4 \pm 7.9$ and $56.3 \pm$ $9.9 \%$ of baseline in layer $2 / 3$ and layer 5 , respectively $(n=4)$. Consistent with a reduction in GABA release, PPR increased from $0.83 \pm 0.03$ to $0.94 \pm 0.04$ in layer $2 / 3(p<0.05)$ and from $0.84 \pm 0.03$ to $0.92 \pm 0.04$ in layer $5(p<0.05)$. Similarly, activation of $\mathrm{D}_{2} \mathrm{Rs}$ by the agonist quinpirole $(1 \mu \mathrm{M})$ also depressed IPSCs evoked in both layers (Fig. 2C). IPSC amplitudes after quinpirole application were $61.3 \pm 8.6$ and $59.3 \pm 8.9 \%$ of baseline in layer $2 / 3$ and layer 5 , respectively $(n=6)$. This reduction was associated with a change in PPR in both layers (layer 2/3, from $0.84 \pm 0.06$ to $0.94 \pm 0.05$; layer 5 , from $0.76 \pm 0.03$ to $0.93 \pm 0.06, p<0.05)$. Thus, activation of $\mathrm{CB}_{1} \mathrm{Rs}$ or $\mathrm{D}_{2} \mathrm{Rs}$ decreases GABAergic transmission in the mouse PFC, most likely via a reduction in GABA release.

WIN and quinpirole inhibition of GABAergic transmission is not exclusive to the mouse PFC. In rat PFC slices, IPSCs evoked by stimulating in layer $2 / 3$ and recording from layer 5 pyramidal cells were also suppressed by $5 \mu \mathrm{M}$ WIN to $41.4 \pm 4.5 \%$ of baseline $(n=5)$ after WIN application, and PPR increased from $0.77 \pm 0.09$ to $0.89 \pm 0.09(p<0.01$, paired $t$ test $)$ (Fig. $3 A)$. The suppression was indeed mediated by $\mathrm{CB}_{1}$ Rs because preincubation with the antagonist AM $251(4 \mu \mathrm{M})$ abolished the WIN effect (91.8 $\pm 3.9 \%$ of baseline, $n=5, p<0.005)$. GABAergic inputs in the rat were also sensitive to quinpirole because bath application of this $\mathrm{D}_{2} \mathrm{R}$ agonist reduced IPSCs to $66.9 \pm 4.6 \%$ of baseline $(n=$ 8 ), an effect that is accompanied by a change in PPR from $0.71 \pm$ 0.07 to $0.81 \pm 0.05(p<0.05)$ (Fig. $3 B)$. Preincubation with the $\mathrm{D}_{2} \mathrm{R}$ 

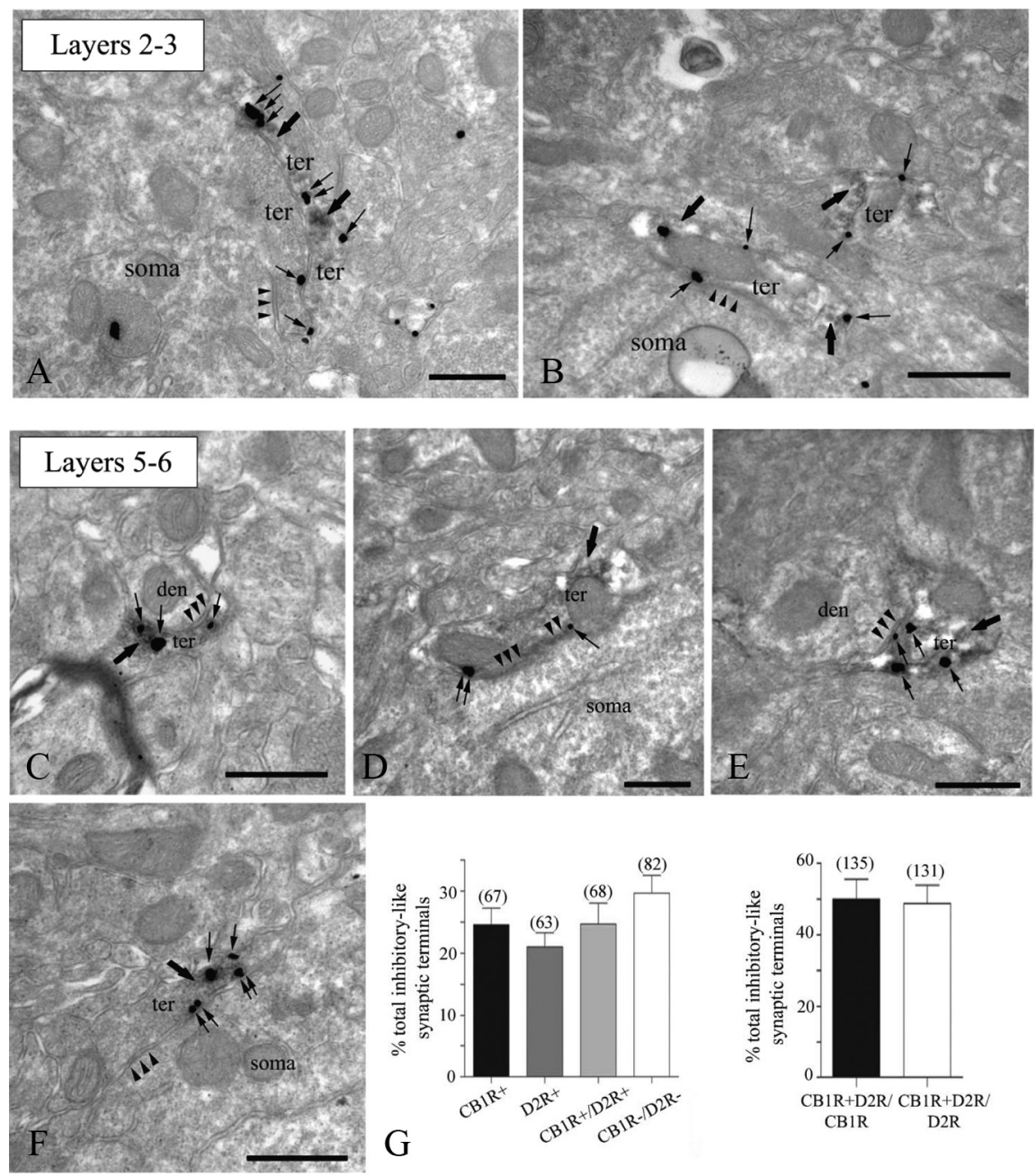

Figure 1. Colocalization of presynaptic $C B_{1} R$ and $D_{2} R$ at symmetrical synapses in the mouse PFC. Double labeling of receptors by combining a pre-embedding immunogold $\left(C_{1} R\right)$ and an immunoperoxidase $\left(D_{2} R\right)$ method for electron microscopy $(A-F)$. $D_{2} R-$ immunoreactive (thick arrows) presynaptic axon terminals (ter) forming symmetrical synapses (arrowheads) with small dendrites (den) and cell bodies (soma) colocalize with $\mathrm{CB}_{1} \mathrm{R}$ immunoparticles (thin arrows) at their perisynaptic and extrasynaptic membranes. Note in $A$ C $B_{1} R$ immunolabeling (thin arrows) in a $D_{2} R$-immunonegative synaptic bouton making a somatic symmetrical synapse (arrowheads). Scale bars, $0.5 \mu \mathrm{m}$. $\mathbf{G}$, Left, percentages (mean \pm SEM) of the total number of symmetrical synapses analyzed $(n=280)$ containing $C_{1} R$ alone, $D_{2}$ R alone, both $C B_{1} R$ and $D_{2} R$, and neither $C_{1} R$ nor $D_{2} R$ in layers $5 / 6$ of the mouse PFC. Right, Approximately $50 \%$ of $\mathrm{CB}_{1} R$-immunopositive inhibitory-like synaptic terminals have $\mathrm{D}_{2}$ R immunoreactivity, and $50 \%$ of $\mathrm{D}_{2} \mathrm{R}$ immunoreactive symmetrical boutons are also equipped with $\mathrm{CB}_{1} \mathrm{R}$ immunometals.

antagonist sulpiride $(10 \mu \mathrm{M})$ blocked quinpirole-induced suppression of GABAergic transmission $(99.0 \pm 3.8 \%$ of baseline, $n=6$, $p<0.005)$, supporting a role for $\mathrm{D}_{2} \mathrm{Rs}$ in this quinpirole effect. Moreover, a different and selective $\mathrm{D}_{2} \mathrm{R}$ agonist, bromocriptine $(2 \mu \mathrm{M})$, also suppressed IPSCs, reducing the amplitude to $72.5 \pm 4.2 \%$ of baseline $(n=6, p<0.005)$ along with a change in PPR from $0.85 \pm 0.04$ to $0.99 \pm 0.07$ ( $p<0.05$, paired $t$ test $)$. Sulpiride also blocked the suppression by bromocriptine (102.5 $\pm 3.6 \%$ of baseline, $n=6, p<0.005$ ). In the striatum, $\mathrm{D}_{2} \mathrm{R}$ activation may lead to eCB mobilization (Giuffrida et al., 1999; Yin and Lovinger, 2006), leading to a reduction in neurotransmitter release via $\mathrm{CB}_{1} \mathrm{R}$ activation (Yin and Lovinger, 2006). To explore this possibility in the $\mathrm{PFC}$, we examined the role of $\mathrm{CB}_{1} \mathrm{Rs}$ in quinpirole suppression of IPSCs; however, AM 251 did not block suppression by quinpirole ( $60.2 \pm 9.5 \%$ of baseline, $n=5$, $p<0.05)$. Together with the EM data showing presynaptic localization of $\mathrm{CB}_{1}$ Rs and $\mathrm{D}_{2} \mathrm{Rs}$, the PPR changes after WIN or quinpirole application support a functional role for $\mathrm{CB}_{1}$ Rs and $\mathrm{D}_{2} \mathrm{Rs}$ in modulating GABA release in both mouse and rat PFC.
Endogenous PKA activity is critical for basal release of GABA and is most likely involved in the suppression of inhibitory transmission by WIN and quinpirole in the PFC

Both $\mathrm{CB}_{1}$ Rs and $\mathrm{D}_{2}$ Rs are coupled to $\mathrm{G}_{\mathrm{i} / \mathrm{o}^{-}}$ proteins, and their activation leads to inhibition of the AC/cAMP/PKA pathway (Howlett et al., 2004; Neve et al., 2004), which may be responsible for the suppression of IPSCs in the PFC by WIN (Figs. $2 B, 3 A$ ) and by quinpirole (Figs. $2 C, 3 B$ ). If this were the case, we expect that directly blocking PKA activity with the inhibitor H89 should also reduce basal GABA release in the PFC. As in the hippocampus (Chevaleyre et al., 2007), bath application of $10 \mu \mathrm{M} \mathrm{H} 89$ resulted in a reduction of IPSCs to layer 5 pyramidal cells $(65.0 \pm 7.4 \%$ of baseline, $n=6)$, which was accompanied by a change in PPR (from $0.72 \pm 0.03$ to $0.84 \pm 0.03, p<$ 0.05 , paired $t$ test) (Fig. $4 A$ ). It is known that inhibition of voltage-gated calcium channels (VGCCs) and PKA contribute to $\mathrm{CB}_{1} \mathrm{R}$-mediated depression of inhibitory transmission (Chevaleyre et al., 2006; Lovinger, 2008; Heifets and Castillo, 2009; Kano et al., 2009); thus, we examined the contribution of PKA in WIN suppression in the PFC by measuring spontaneous miniature IPSCs (mIPSCs) to reduce contamination by the VGCC-sensitive component (Fig. 4B). As reported previously (Vaughan et al., 1999; Takahashi and Linden, 2000; Trettel and Levine, 2002; Chevaleyre et al., 2007), WIN (5 $\mu \mathrm{M})$ reduced mIPSC frequency (from $4.14 \pm$ 0.99 to $2.00 \pm 0.41 \mathrm{~Hz}, n=4, p<0.05$, paired $t$ test) but not amplitude (from $11.3 \pm 1.8$ to $10.5 \pm 1.5 \mathrm{pA}, p>0.05$, paired $t$ test). Preincubating PFC slices in $10 \mu \mathrm{M}$ H89 lowered mIPSC frequency $(1.62 \pm 0.29 \mathrm{~Hz}, n=5, p<0.05)$ and occluded additional reduction by subsequent WIN application $(1.50 \pm 0.19 \mathrm{~Hz}, n=5, p>0.05$, paired $t$ test). The mechanism by which $\mathrm{D}_{2}$ Rs suppress GABA release is less clear. One study in the ventral tegmental area (VTA) suggests that activation of $\mathrm{D}_{2} \mathrm{Rs}$ at the presynaptic terminal may suppress inhibitory transmission solely via a decrease in PKA activity (Pan et al., 2008). Another study using two-photon calcium imaging of axonal varicosities of VTA medium spiny neurons also implicate calcium sources in $\mathrm{D}_{2} \mathrm{R}$-mediated inhibition (Mizuno et al., 2007). We tested whether quinpirole suppression is sensitive to PKA inhibition and found that, in slices preincubated in H89, evoked IPSC amplitudes were unchanged after quinpirole application (108.9 $\pm 9.4 \%$ of baseline, $n=4)$ (Fig. $4 C$ ). To confirm that the lack of quinpirole suppression in H89 indeed resulted from inhibition of PKA activity, we also used the potent cellmembrane-permeable PKA inhibitor peptide PKI 14-22 and found similar block of the quinpirole effect $(97.4 \pm 6.1 \%$ of baseline, $n=6, p<0.005)$. Thus, our results strongly suggest that PKA activity is involved in basal GABA release, and, by 
A

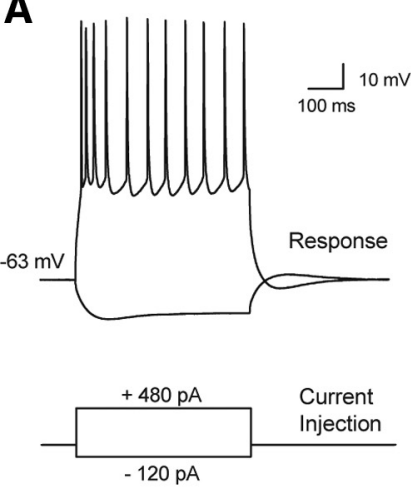

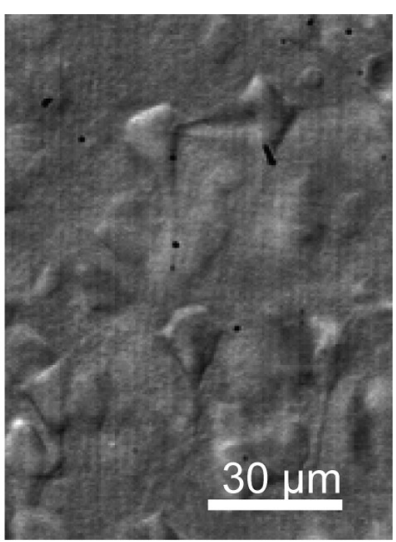

B
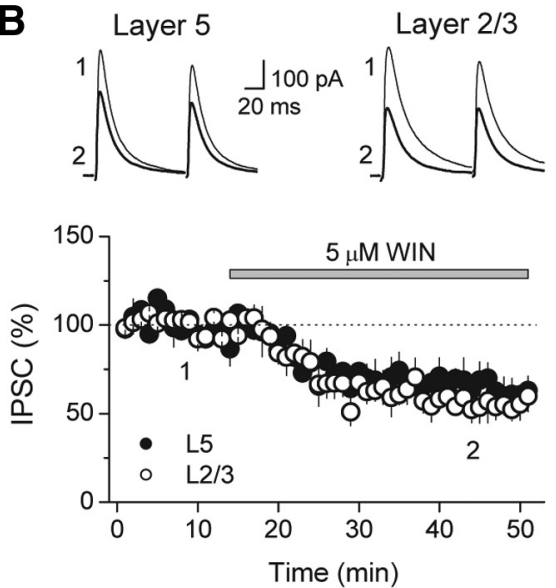

C
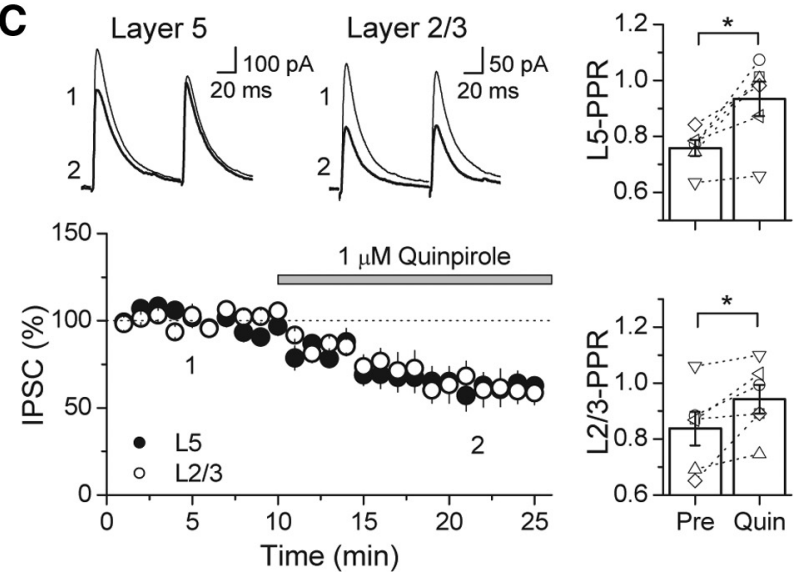

Figure 2. Pharmacological activation of $C B_{1} R s$ or $D_{2} R s$ suppresses $G A B A$ ergic responses evoked by stimulation in layers (L) $2 / 3$ and 5 in the mouse PFC. $A$, Left, Representative response of whole-cell patched layer 5 pyramidal cell in current clamp (above) while depolarizing or hyperpolarizing current injections were delivered (below) to show that targeting cells in layer 5 by their shape is a reliable way of patching pyramidal cells. Note the initial spike adaption, followed by a slow regular spiking behavior. Right, Photograph of image under IR-DIC microscopy of a patched cell in layer 5 of the PFC exhibiting a pyramidal cell-like morphology. $\boldsymbol{B}$, Time course of WIN 55,212-2 suppression on both proximal (black circles) and distal (white circles) GABAergic inputs in the mouse PFC ( $n=4$ cells). Top, Representative average IPSC traces from a single experiment, obtained at the time points in the time course graph. Right, Bar graph of the average PPR before and after WIN application. Open symbols represent the PPR of individual experiments. C, Time course of quinpirole (Quin) suppression on both proximal (black circles) and distal (white circles) GABAergic inputs in the mouse PFC ( $n=6$ cells). Top, Representative average IPSC traces from an individual experiment, obtained at the time points indicated. Right, Bar graph of the average PPR before and after quinpirole application. Open symbols represent the PPR of individual experiments. ${ }^{*} p<0.05$. inhibiting this activity, $\mathrm{CB}_{1}$ Rs or $\mathrm{D}_{2} \mathrm{Rs}$ can suppress GABAergic transmission.

\section{Pharmacological activation of $D_{2}$ Rs facilitates induction of I-LTD}

Our EM images show colocalization of $\mathrm{CB}_{1} \mathrm{Rs}$ and $\mathrm{D}_{2}$ Rs at terminals of symmetrical synapses in the PFC, and we have provided functional evidence that independent activation of either receptor suppresses GABA release. Given that both $\mathrm{CB}_{1}$ Rs and $\mathrm{D}_{2} \mathrm{Rs}$ can signal via PKA inhibition (Howlett et al., 2004; Neve et al., 2004), we next wondered whether simultaneous activation of both receptors will reveal an interaction between $\mathrm{D}_{2} \mathrm{R}$ - and $\mathrm{CB}_{1} \mathrm{R}$-mediated effects. To this aim, we applied a low dose of quinpirole $(500 \mathrm{nM})$ in the absence or presence of a submaximal concentration of WIN (50 nM) (Fig. 5A). Interestingly, although by itself $500 \mathrm{~nm}$ quinpirole had very little effect of basal IPSC amplitude $(96.2 \pm 6.2 \%$ of baseline, $n=10)$, it significantly decreased IPSCs when $\mathrm{CB}_{1}$ Rs were coactivated $(78.4 \pm 10.7 \%$ of baseline, $n=8, p<0.05)$. We next tested whether $\mathrm{D}_{2} \mathrm{R}$ activation could enhance eCB signaling in the $\mathrm{PFC}$ by delivering a $5 \mathrm{~Hz}$ train of synaptic stimulation (see Materials and Methods) in the presence of $500 \mathrm{~nm}$ quinpirole. Although on its own the $5 \mathrm{~Hz}$ stimulation was below threshold to trigger I-LTD, it became suprathreshold when $\mathrm{D}_{2}$ Rs were activated (Fig. $5 B$ ). IPSC amplitudes after train were $97.6 \pm 11.0 \%$ of baseline $(n=5)$ and $60.6 \pm 3.3 \%$ of baseline $(n=$ 14 ) in the absence and presence of quinpirole, respectively ( $p<$ $0.005)$. Consistent with a role for $\mathrm{D}_{2}$ Rs, I-LTD was abolished in the presence of sulpiride (98.6 $\pm 2.2 \%$ of baseline, $n=4, p<$ 0.01) (Fig. 5C). Importantly, I-LTD was dependent on $\mathrm{CB}_{1} \mathrm{R}$ activation because it was blocked in AM $251(99.6 \pm 11.9 \%$ of baseline, $n=5, p<0.01$ ) (Fig. $5 D$ ) and was occluded by preincubation with $5 \mu \mathrm{M}$ WIN $(99.1 \pm 7.6 \%$ of baseline, $n=6, p<$ 0.01) (Fig. 5E).

In many brain regions, $\mathrm{eCB}$ mobilization in LTD is triggered by activation of group I metabotropic glutamate receptors (mGluRs) (Chevaleyre et al., 2006; Heifets and Castillo, 2009; Kano et al., 2009). Given evidence of the expression of these receptors in cell bodies and dendritic bundles of PFC pyramidal cells in layer 5 (Defagot et al., 2002; Lafourcade et al., 2007), we next examined the involvement of group I mGluRs in I-LTD. Indeed, I-LTD was abolished by the group I mGluR antagonists LY367385 and MPEP ( $98.9 \pm 8.9 \%$ of baseline, $n=6, p<0.005)$, whereas interleaved I-LTD controls were normal $(55.7 \pm 5.2 \%$ of baseline, $n=6$ ) (Fig. $5 F$ ). Thus, despite the need for quinpirole, I-LTD in the PFC is similar to the more classical form of eCBLTD in other brain regions in that its induction requires group I mGluR activation.

\section{DA facilitation of I-LTD most likely occurs via synergism between presynaptic $D_{2} R$ and $C B_{1} R$ signaling}

$\mathrm{D}_{2}$ Rs may act at several sites to facilitate I-LTD. We investigated the different possibilities in the following experiments. First, we tested whether $\mathrm{D}_{2}$ Rs postsynaptically enhance $\mathrm{eCB}$ production and release in the PFC as has been suggested in the striatum and VTA (Giuffrida et al., 1999; Melis et al., 2004; Yin and Lovinger, 2006). Given that the AC/cAMP/PKA pathway is a principal effector of $\mathrm{D}_{2} \mathrm{R}$-mediated effects (Neve et al., 2004), we blocked PKA in the entire slice by bath application of $\mathrm{H} 89(10 \mu \mathrm{M})$ or PKI 14-22 $(2.5 \mu \mathrm{M})$ and compared this effect with inhibiting PKA specifically in the postsynaptic cell (Fig. 6A). Consistent with a presynaptic site of action by $\mathrm{D}_{2} \mathrm{Rs}$, bath application of $\mathrm{H} 89$ or PKI 14-22 abolished I-LTD ( $92.6 \pm 4.9 \%$ of baseline, $n=6, p<0.01$; and $97.0 \pm 14.3 \%$ of baseline, $n=6, p<0.01$, respectively), 
A
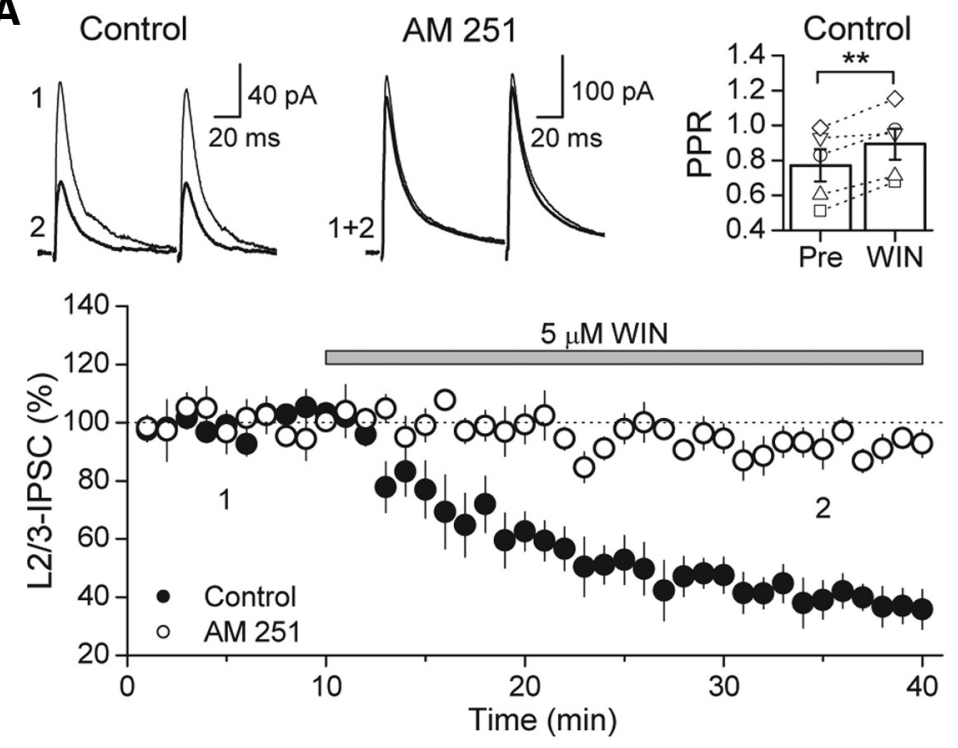

B
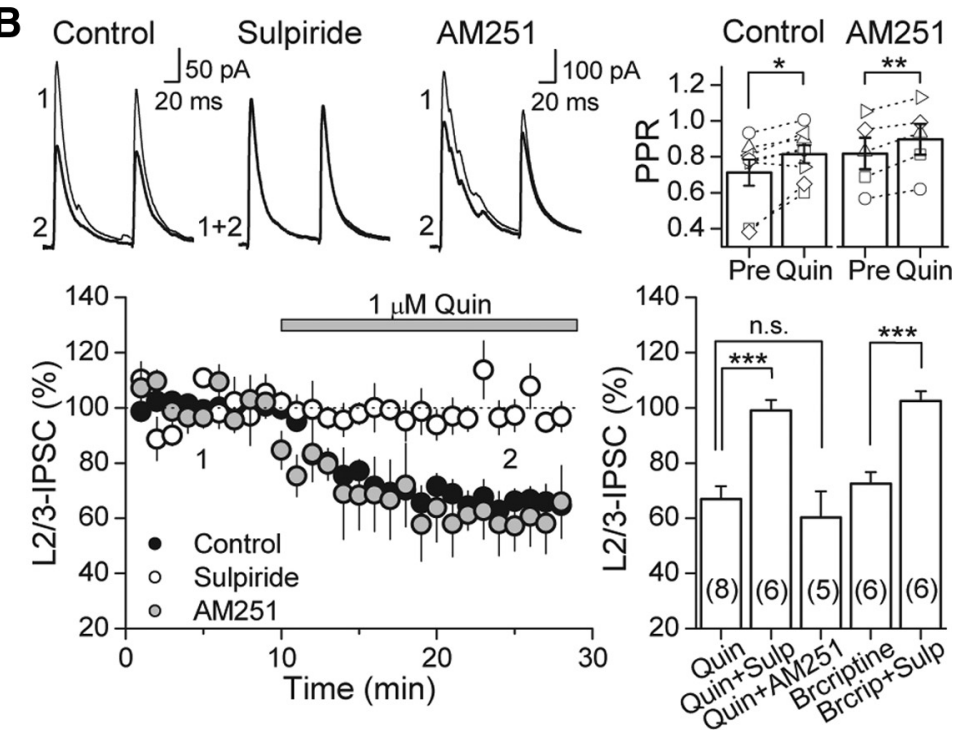

Figure 3. Activation of $C_{1} B_{1}$ or $D_{2} R$ suppresses $G A B A$ ergic transmission in the rat PFC. $A$, Time course of WIN suppression of IPSC amplitudes in the rat PFC (black circles), which is abolished in $\mathrm{CB}_{1} \mathrm{R}$ blockade with $4 \mu \mathrm{M}$ AM 251 (white circles). Top left, Representative average IPSC traces from a single control experiment, obtained at time points indicated. Top right, PPR plot before and after WIN application. PPR of layer (L) 2/3 IPSCs significantly increased. Open symbols represent the PPR of individual experiments. $B$, Time course of quinpirole (Quin) suppression of IPSC amplitudes in the rat PFC in control (black circles), under $\mathrm{D}_{2} \mathrm{R}$ antagonism with $10 \mu \mathrm{m}$ sulpiride (Sulp; white circles), and under (B, R block with $4 \mu \mathrm{M}$ AM 251 (gray circles). Top left, Representative average IPSC traces from a single control experiment. Top right, PPR plot before and after quinpirole application. PPR of layer 2/3 IPSCs significantly increased under control conditions and in AM 251. Open symbols represent the PPR of individual experiments. Bottom right, Summary plot of suppression mediated by $D_{2} R$ agonists quinpirole $(1 \mu \mathrm{M})$ and bromocriptine (Brcriptine; $\left.2 \mu \mathrm{M}\right)$. Effects of both drugs were blocked by sulpiride. However, AM 251 had no effect on quinpirole suppression. The number of experiments for each condition is indicated in parentheses. ${ }^{*} p<0.05,{ }^{* *} p<0.01,{ }^{* *} p<0.005$.

whereas loading the membrane-impermeable PKI 6-22 peptide $(2.5$ or $100 \mu \mathrm{M}$ ) into the patch pipette did not prevent I-LTD (57.9 $\pm 5.6 \%$ of baseline, $n=4$; and $53.8 \pm 5.1 \%$ of baseline, $n=$ 5 , respectively). We verified that this loading procedure could reliably inhibit postsynaptic PKA by assaying the ability of the PKI peptide to reduce the PKA-dependent inhibition of the slow AHP current $\left(I_{\mathrm{AHP}}\right)$ in CA1 pyramidal cells. Interestingly, loading PKI 6-22 at 2.5 or $100 \mu \mathrm{M}$ were equally effective at decreasing the inhibition of slow $I_{\mathrm{AHP}}$ induced by bath application of the PKA activator Sp-cAMPS (Fig. 6B). Hence, although I-LTD in the PFC is dependent on PKA activity, it appears that postsynaptic PKA does not play a significant role.
Although inhibition of PKA activity is a main target of $D_{2} R$ signaling, alternative molecular players such as intracellular calcium stores have been linked to $\mathrm{D}_{2} \mathrm{R}$-mediated effects (Nishi et al., 1997; Hernandez-Lopez et al., 2000). We tested whether intracellular calcium rise is necessary for eCB mobilization in I-LTD by loading the postsynaptic cell with the fast calcium chelator BAPTA (Fig. $6 C$ ). In the presence of quinpirole, the $5 \mathrm{~Hz}$ train of synaptic stimulation still led to a longlasting depression of IPSCs in the PFC (59.6 $\pm 6.6 \%$ of baseline, $n=5$ ). Thus, similar to the hippocampus (Chevaleyre and Castillo, 2003) and amygdala (Azad et al., 2004), I-LTD in the PFC does not require postsynaptic calcium increases, further bolstering the idea that postsynaptic $\mathrm{D}_{2}$ Rs are not involved. Our findings that $\mathrm{D}_{2}$ Rs also localize to presynaptic inhibitory-like terminals and that activation of these receptors may reduce GABA release via PKA inhibition make presynaptic $\mathrm{D}_{2}$ Rs the most likely mediators of I-LTD facilitation.

In the hippocampus, the level of spontaneous GABAergic activity can determine whether I-LTD occurs (Heifets et al., 2008). It was shown that I-LTD requires calcium increases at GABAergic terminals during the induction step, via the recruitment of calcium-dependent protein kinases and phosphatases. In the PFC, activation of $\mathrm{D}_{2}$ Rs may increase interneuronal excitability and thus spontaneous inhibitory activity (Retaux et al., 1991; Grobin and Deutch, 1998). Although this effect is not seen by all (Gorelova and Yang, 2000; Seamans et al., 2001; Tseng and O'Donnell, 2007), it is formally possible that quinpirole may indirectly facilitate I-LTD in the PFC by enhancing the activity of interneurons whose terminals express $\mathrm{CB}_{1} \mathrm{Rs}$. We examined whether sIPSC frequency increased in our hands after $500 \mathrm{~nm}$ quinpirole application but found no difference $(20.8 \pm 4.0 \mathrm{~Hz}$ before vs $17.7 \pm 2.8 \mathrm{~Hz}$ after, $p>0.05, n=9)$. Thus, an increase in spontaneous inhibitory activity cannot account for the facilitatory effect of quinpirole on eCB signaling.

\section{Endogenous DA facilitates I-LTD when} catechol-O-methyltransferase is inhibited

Thus far, we have activated $\mathrm{D}_{2}$ Rs by applying the specific receptor agonist quinpirole. We next sought to determine whether endogenous DA can also facilitate eCB signaling. It is possible that DA deafferentation that is inherent to the slicing procedure prevented the $5 \mathrm{~Hz}$ train from triggering I-LTD in the absence of quinpirole. To compensate for a reduction of DA levels that is highly expected in PFC slices, we pharmacologically blocked DA 
A

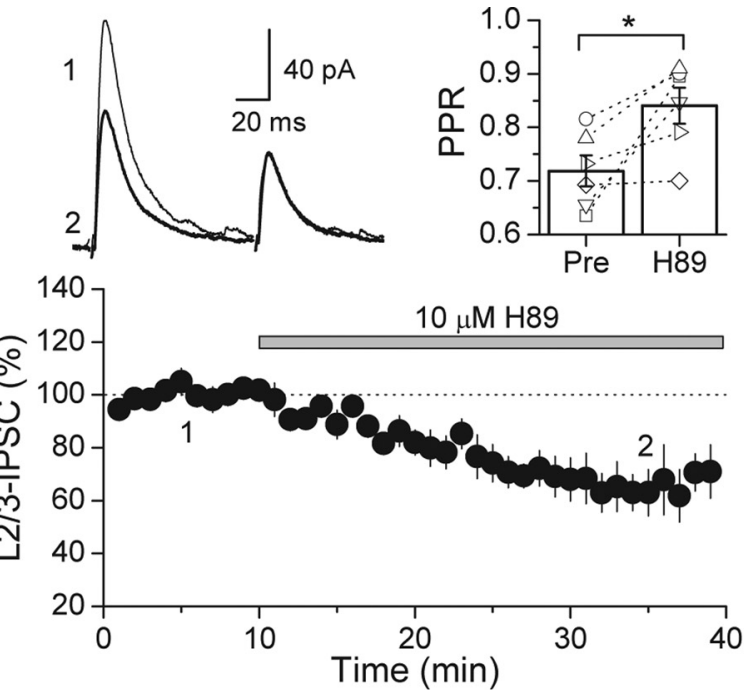

B

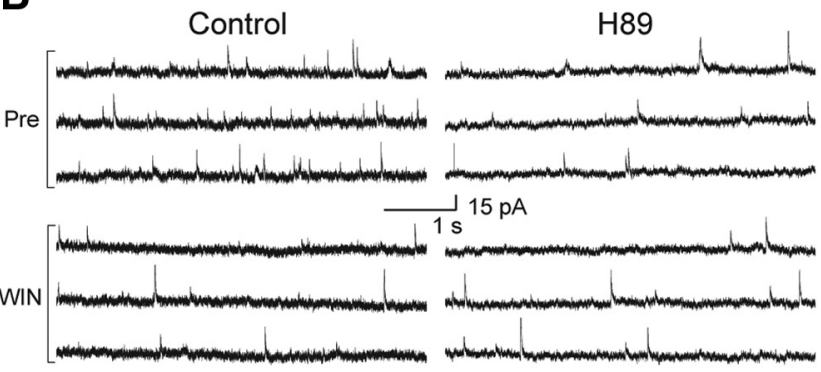

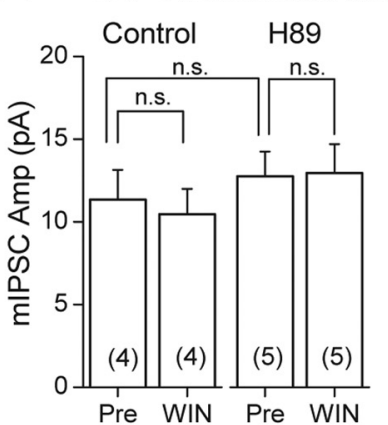

Pre WIN Pre WIN

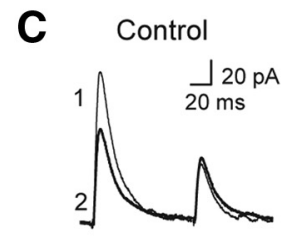

$\mathrm{H} 89$
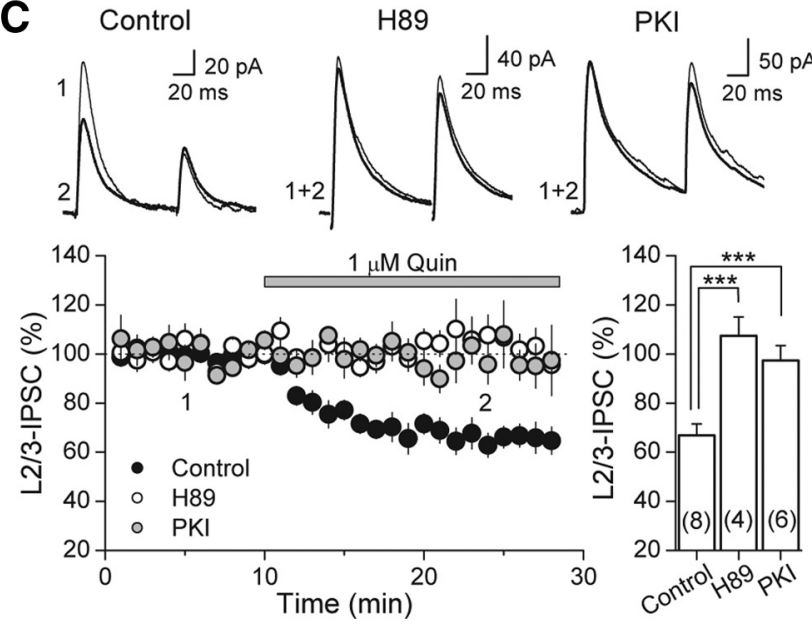

Figure 4. Inhibiting PKA activity with $\mathrm{H} 89$ reduces GABA release and occludes WIN and quinpirole suppression of GABAergic transmission in the rat PFC. $A$, Time course of $\mathrm{H} 89$ suppression of IPSC amplitudes in the rat PFC ( $n=6$ cells). Top left, Representative average IPSC traces from a single experiment, obtained at the time points indicated. Top right, PPR plot before and after H89 application. PPR of layer (L) 2/3 IPSCs significantly increased. Open symbols represent catabolism and tested whether synaptic stimulation will trigger I-LTD under this recording condition (Fig. 7). The major mammalian enzymes involved in the degradation of DA are catechol$O$-methyltransferase (COMT) and monoamine oxidases, with relative contribution tilted toward COMT in the PFC (Karoum et al., 1994; Matsumoto et al., 2003; Yavich et al., 2007). Thus, to effectively increase DA levels in PFC slices, we pharmacologically blocked COMT activity with the inhibitor OR $486(2 \mu \mathrm{M})$. The 5 $\mathrm{Hz}$ train failed to trigger I-LTD in the presence of OR 486 alone $(100.4 \pm 21.1 \%$ of baseline, $n=4)$ (supplemental Fig. S1, available at www.jneurosci.org as supplemental material). Because DA can activate both $D_{1}$ Rs and $D_{2}$ Rs, with potentially opposing effects (Cepeda et al., 1993; Nishi et al., 1997; Seamans et al., 2001; Trantham-Davidson et al., 2004; Tseng and O'Donnell, 2004; Xu et al., 2009), an effect by $\mathrm{D}_{2}$ Rs may potentially be masked by a conflicting $\mathrm{D}_{1} \mathrm{R}$ effect, depending on which receptor was more strongly activated. Therefore, we next tested I-LTD by coapplication of OR 486 with the $\mathrm{D}_{1} \mathrm{R}$ antagonist SCH23390 $(10 \mu \mathrm{M})$. Indeed, in the presence of OR 486 and SCH23390, I-LTD could be triggered by the $5 \mathrm{~Hz}$ synaptic stimulation (IPSC amplitude, $49.6 \pm 4.6 \%$ of baseline, $n=10$ ) (Fig. 7A). Consistent with a reduction in probability of GABA release, PPR in I-LTD experiments increased from $0.82 \pm 0.03$ to $0.92 \pm 0.04(p<0.05$, paired $t$ test). A role for $\mathrm{D}_{2}$ Rs was confirmed by the ability of sulpiride to reduce I-LTD in the presence of OR $486(88.5 \pm 8.4 \%$ of baseline, $n=8, p<0.005$ ) (Fig. 7A). As was observed for the quinpirole-facilitated form, I-LTD in OR 486 and SCH23390 was also sensitive to $\mathrm{CB}_{1} \mathrm{R}$ blockade with $\mathrm{AM} 251(93.0 \pm 9.8 \%$ of baseline, $n=6, p<0.01$ ) (Fig. $7 B$ ) and was not present in the $\mathrm{CB}_{1} \mathrm{R}$ knock-out mice (knock-out, $92.2 \pm 4.8 \%$ of baseline, $n=$ 7 vs WT, $70.7 \pm 3.8 \%$ of baseline, $n=7, p<0.005$ ) (Fig. $7 C$ ). Consistent with a role for PKA in $\mathrm{D}_{2} \mathrm{R}$ - and $\mathrm{CB}_{1} \mathrm{R}$-mediated effects on GABAergic transmission in the PFC, I-LTD in the presence of OR 486 and SCH23390 was reduced in H89 (91.0 $\pm 5.7 \%$ of baseline, $n=6, p<0.005$ ) (Fig. $7 D$ ). Thus, together, our results strongly suggest that endogenous DA can activate $\mathrm{D}_{2}$ Rs in the presynaptic GABAergic terminal to enhance eCB signaling and trigger I-LTD.

\section{Discussion}

In this study, we combine anatomical and electrophysiological techniques to investigate the cellular mechanisms underlying the link between DA and eCB function in the PFC. Using EM, we first show immunolabeling of $\mathrm{D}_{2} \mathrm{Rs}$ and $\mathrm{CB}_{1}$ Rs at terminals of symmetrical presumably GABAergic synapses in the PFC. Notably, quantitative analysis reveal a robust pattern of $\mathrm{CB}_{1} \mathrm{R}$ and $\mathrm{D}_{2} \mathrm{R}$ colocalization at these presynaptic sites. Consistent with this localization, activation of either receptor suppresses GABA release as indicated by an increase in PPR. Importantly, repetitive afferent stimulation in the presence of a $\mathrm{D}_{2} \mathrm{R}$ agonist induces eCB-dependent I-LTD that is insensitive to interference of

the PPR of individual experiments. $\boldsymbol{B}$, WIN suppression of mIPSC frequency in control is absent in slices preincubated in $10 \mu \mathrm{m}$ H89. Top left, Three representative mIPSC traces from a single control experiment before and after WIN application. Top right, Three representative mIPSC traces from a single $\mathrm{H} 89$ experiment before and after WIN application. C, Quinpirole (Quin) suppression of IPS (amplitudes in control (black circles) is absent in slices preincubated in either $10 \mu \mathrm{m} \mathrm{H89}$ (white circles) or $2.5 \mu \mathrm{m}$ PKI 14-22 (gray circles). Top, Representative average IPSC traces from single experiments. Bottom right, Summary plot of quinpirole suppression in control and block under PKA inhibition by $\mathrm{H} 89$ and PKI $14-22$. The number of experiments for each condition is indicated in parentheses. ${ }^{*} p<0.05,{ }^{* * *} p<0.005$. 

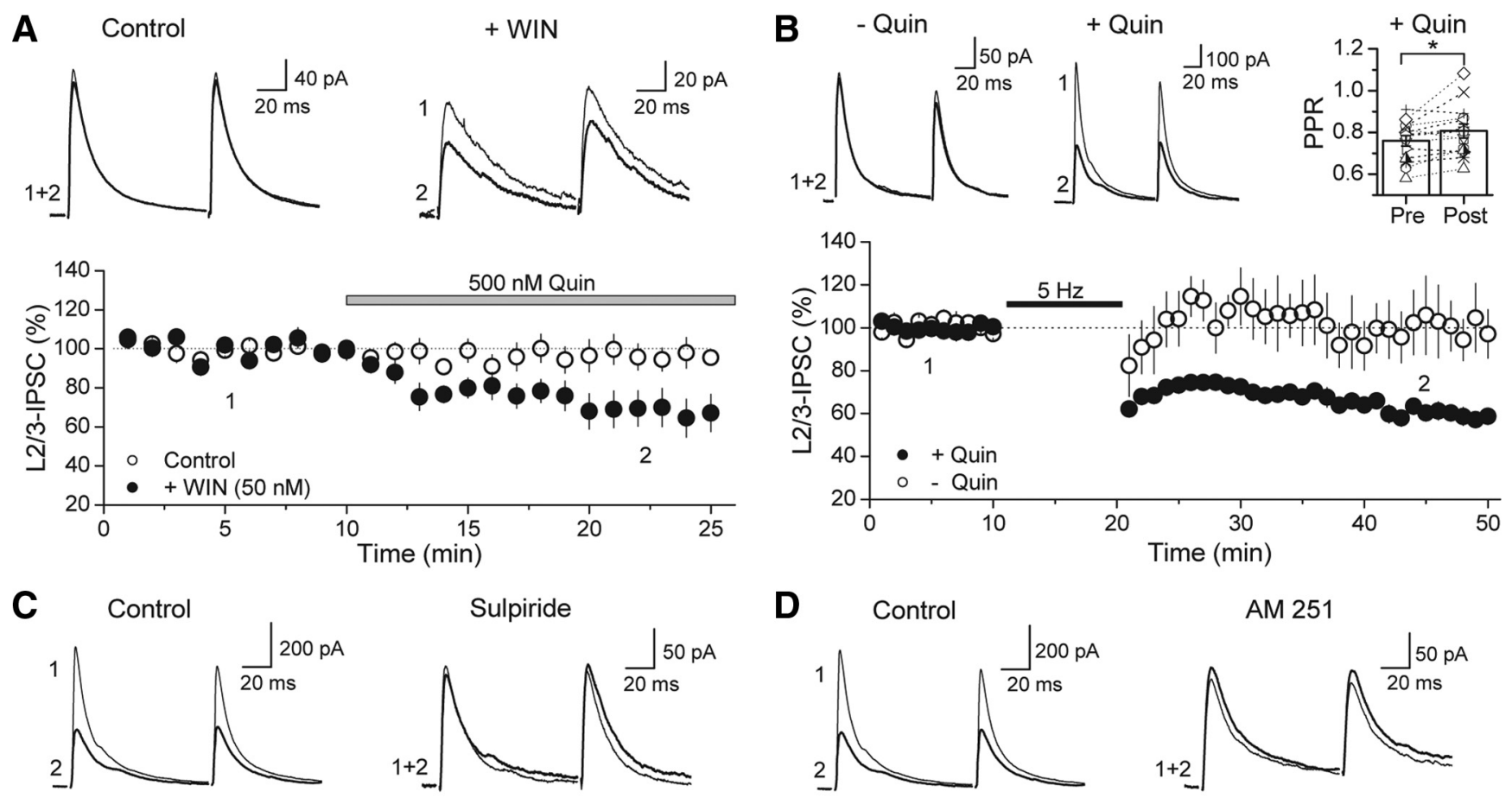

D Control

AM 251
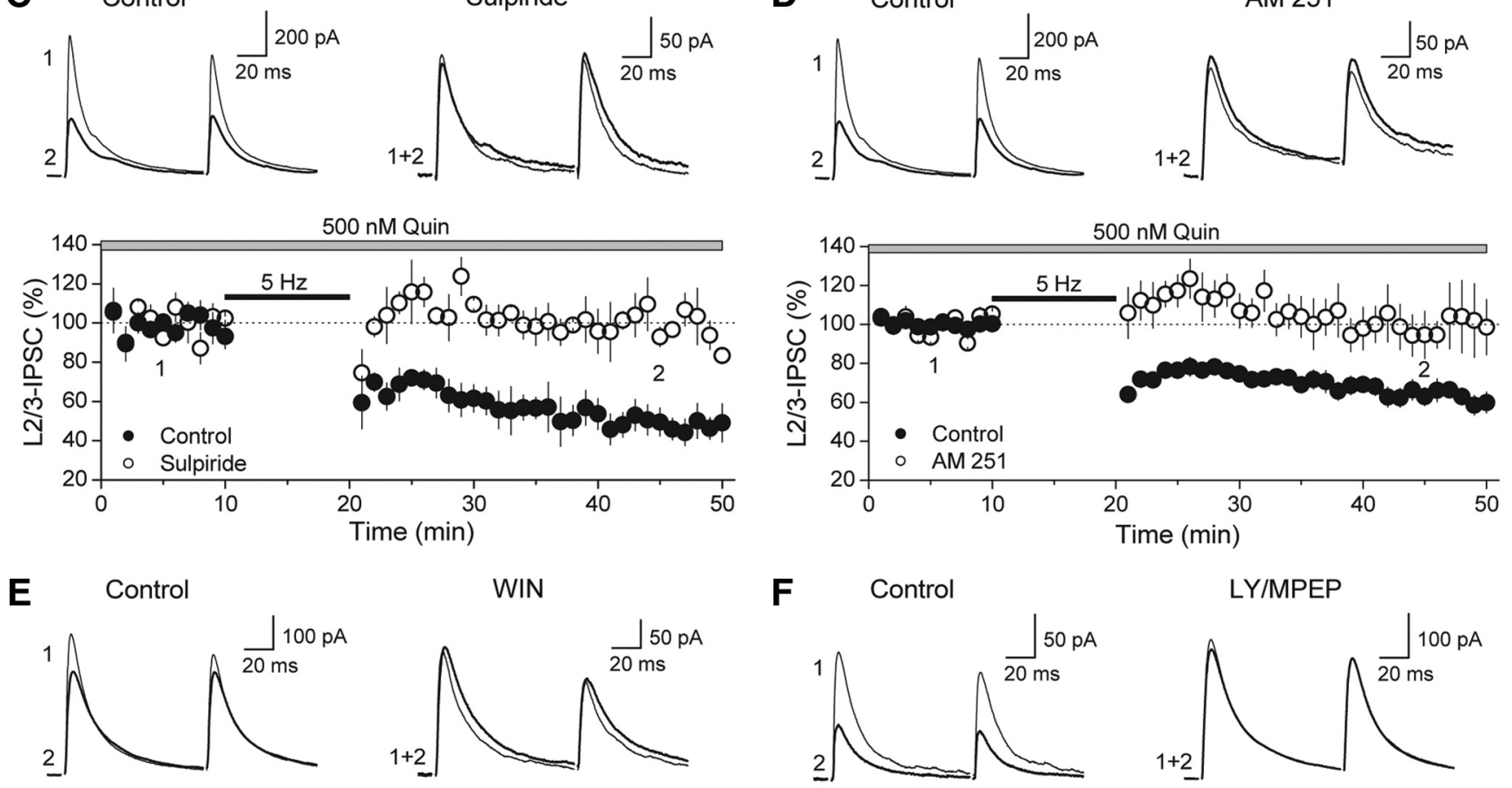

WIN

$\mathbf{F}$

Control

LY/MPEP
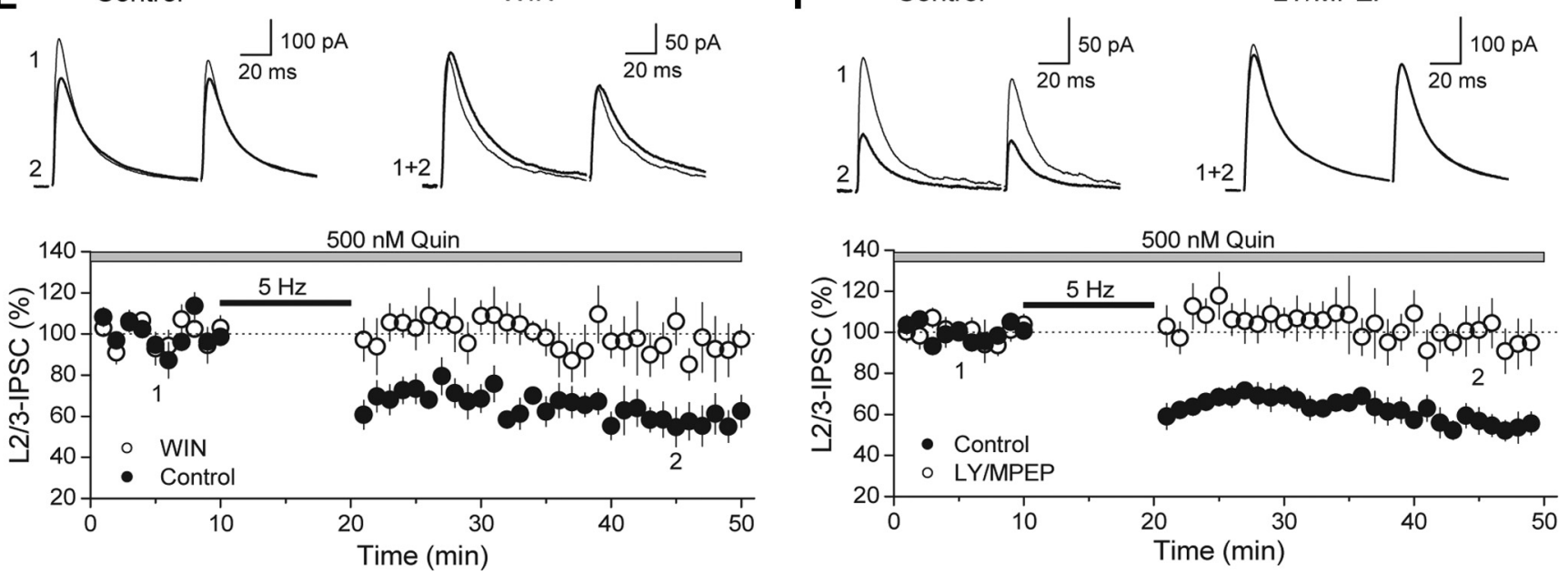

Figure 5. I-LTD can be triggered by a $5 \mathrm{~Hz}$ train of synaptic stimulation in the presence of low-dose quinpirole. A, Time course of $500 \mathrm{~nm}$ quinpirole effect on IPSC amplitude in the presence (black circles) or absence (white circles) of $50 \mathrm{~nm}$ WIN. Preincubation with a submaximal dose of WIN (+WIN) reveals the suppressive effect of an otherwise ineffective dose of quinpirole (control). Top, Representative average IPSC traces from single experiments obtained from the time points indicated. $\boldsymbol{B}$, Time course plot of average IPSC amplitudes before and after $5 \mathrm{~Hz}$ stimulation train in the absence (white circles) or presence (black circles) of quinpirole. Responses only persistently depressed as a result of $5 \mathrm{~Hz}$ stimulation when $\mathrm{D}_{2}$ Ragonist is in the bath (+ Quin). Top left, Representative average IPSC traces from single experiments obtained from the time points indicated. Top right, Plot of PPR before and after train in the presence of $\mathrm{D}_{2}$ Ragonist. Open symbols represent single experiments. C, Time course of control I-LTD (black circles) and the absence ofl-LTD under $D_{2}$ Rantagonism with $10 \mu$ m sulpiride (white circles). Top, Representative average IPSC traces from a single control and sulpiride block experiment. D, Time course of control I-LTD (black circles) and the absence of I-LTD in the presence of $4 \mu \mathrm{M}$ AM 251 (white circles). Top, Representative average IPSC traces from a single control and AM 251 block experiment. $\boldsymbol{E}$, Time course of control I-LTD (black circles) and its absence in slices that were preincubated in $5 \mu \mathrm{m}$ WIN (white circles). Top, Representative average IPSC traces from a single control and WIN occlusion experiment. $\boldsymbol{F}$, Time course of contro I-LTD (black circles) and the lack of I-LTD in the presence of group I mGluR antagonists (white circles). Top, Representative average IPSC traces from single control and block experiments. ${ }^{*} p<0.05$. L, Layer; LY, LY367385. 

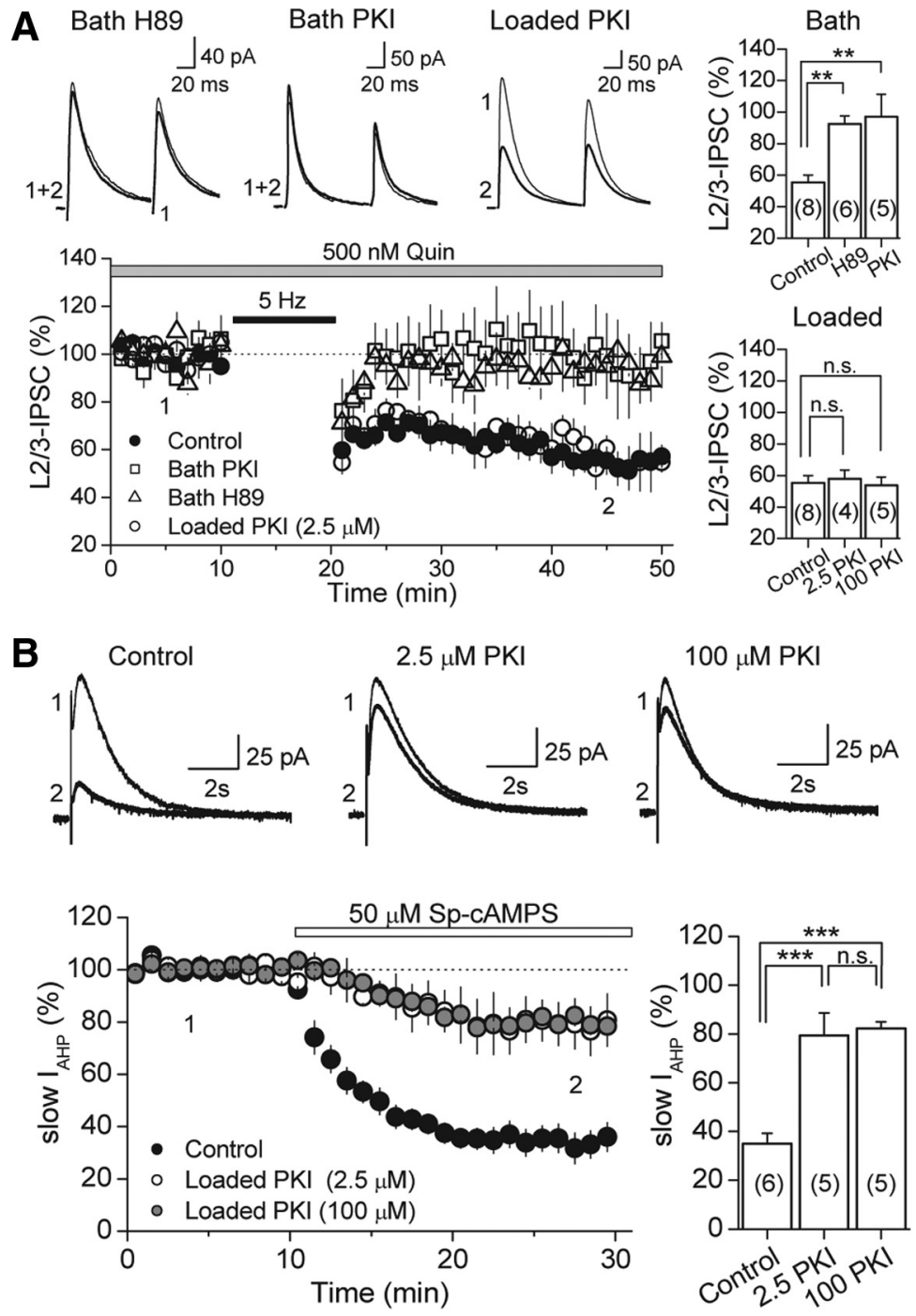

\section{Control}

BAPTA
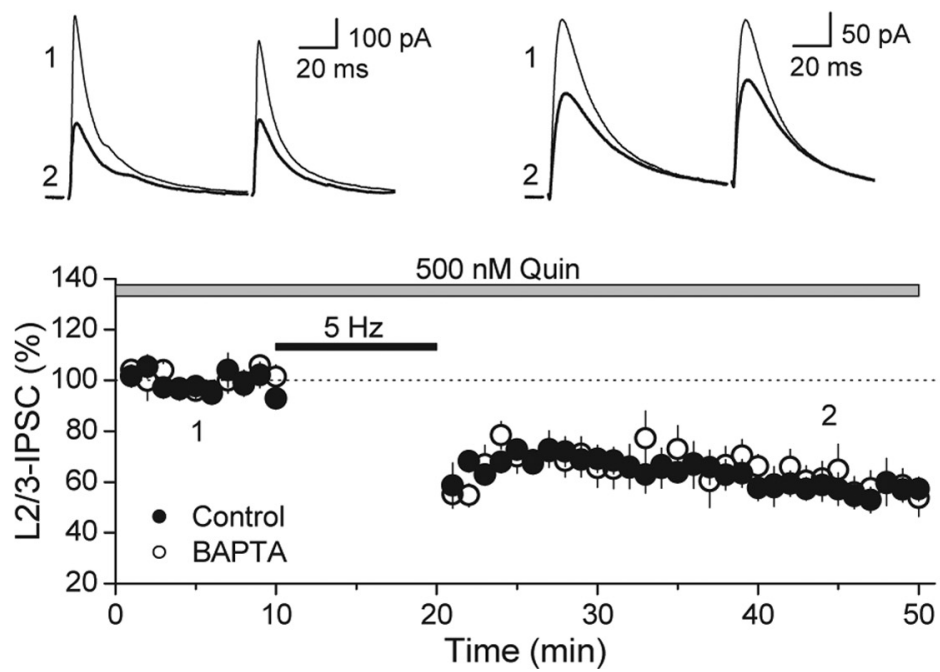

Figure 6. Neither postsynaptic PKA nor intracellular calcium rise is required for I-LTD. $\boldsymbol{A}$, Time course of I-LTD in interleaved controls (black circles), bath-applied H89 (10 $\mu \mathrm{m}$; white triangles), bath-applied PKI 14 -22 peptide ( $2.5 \mu \mathrm{m}$; white squares), and cells loaded with $2.5 \mu \mathrm{m}$ PKI 6-22 peptide (white circles). Inhibiting PKA activity in the slice blocks I-LTD, but inclusion of PKI (at either 2.5 or $100 \mu \mathrm{m}$ ) in the postsynaptic cell does not, as depicted in the summary bar plots on the top and bottom right. Top, Representative average IPSC traces from single $\mathrm{H} 89$ and PKI experiments obtained from the time points indicated. $\boldsymbol{B}$, Verification that intracellular loading of the PKI 6-22 peptide effectively inhibits postsynaptic PKA activity. PKI loaded into CA1 pyramidal cells postsynaptic $D_{2} R$ signaling. Together, our results strongly suggest a synergistic interaction between colocalized $\mathrm{D}_{2} \mathrm{Rs}$ and $\mathrm{CB}_{1} \mathrm{Rs}$ in regulating long-term depression of inhibitory transmission in the PFC.

Previous studies have shown that activation of $\mathrm{CB}_{1} \mathrm{Rs}$ in neocortex (Trettel and Levine, 2002; Bodor et al., 2005; Hill et al., 2007; Galarreta et al., 2008) or $\mathrm{D}_{2} \mathrm{Rs}$ in prefrontal cortex (Retaux et al., 1991; Seamans et al., 2001) can suppress inhibitory transmission, presumably by reducing GABA release. Our combined anatomical and physiological data support similar roles of $\mathrm{CB}_{1}$ Rs and $\mathrm{D}_{2}$ Rs on GABAergic transmission in the PFC. Furthermore, in keeping with a recent report in the nucleus accumbens (Pickel et al., 2006), we have found that $\mathrm{D}_{2}$ Rs and $\mathrm{CB}_{1}$ Rs can colocalize to sites presynaptic to symmetrical synapses in the PFC; this colocalization may provide an anatomical substrate for receptor interaction when coactivated. Coactivation of $\mathrm{CB}_{1} \mathrm{Rs}$ and $\mathrm{D}_{2}$ Rs can have several potential effects on signal transduction of the respective individual receptors. In heterologous systems and striatal cultures, pharmacological coactivation of coexpressed $\mathrm{CB}_{1} \mathrm{Rs}$ and $\mathrm{D}_{2} \mathrm{Rs}$ has been shown to alter G-protein signaling, converting $\mathrm{G}_{\mathrm{i} / \mathrm{o}}$-mediated pathways to $\mathrm{G}_{\mathrm{s}}$ coupled ones (Glass and Felder, 1997; Kearn et al., 2005), thereby enhancing rather than reducing transmitter release. There is also the possibility of synergistic or antagonistic crosstalk between the receptor systems in the presynapse (Kearn et al., 2005; Marcellino et al., 2008).

We have tested for a potential interaction between the eCB and DA systems in the PFC and found that nominal activation of $\mathrm{D}_{2}$ Rs with a low dose of quinpirole can facilitate eCB signaling at GABAergic synapses to trigger I-LTD. $\mathrm{D}_{2}$ Rs most likely act by enhancing a process downstream of eCB mobilization from the postsynaptic cell because blocking postsynaptic PKA activity has no effect on I-LTD, whereas global block of PKA in the

$\leftarrow$

at either 2.5 or $100 \mu \mathrm{m}$ significantly reduced the inhibition of slow AHP current $\left(I_{\text {AHP }}\right)$ induced by bath application of a specific PKA activator (Sp-CAMPS). Top, Representative average AHP traces from single experiments at the time points indicated. Bottom right, Summary bar plot depicting the effect of loading PKI on slow $I_{\text {AHP }}$ inhibition. C, Time course of I-LTD in control (black circles) and in cells loaded with $20 \mathrm{~mm}$ BAPTA (white circles). Chelating postsynaptic calcium has no effect on I-LTD. Top, Representative average IPSC traces from single experiments. The number of experiments for each condition is indicated in parentheses. ${ }^{* *} p<0.01,{ }^{* * *} p<0.005$. L, Layer; Quin, quinpirole. 

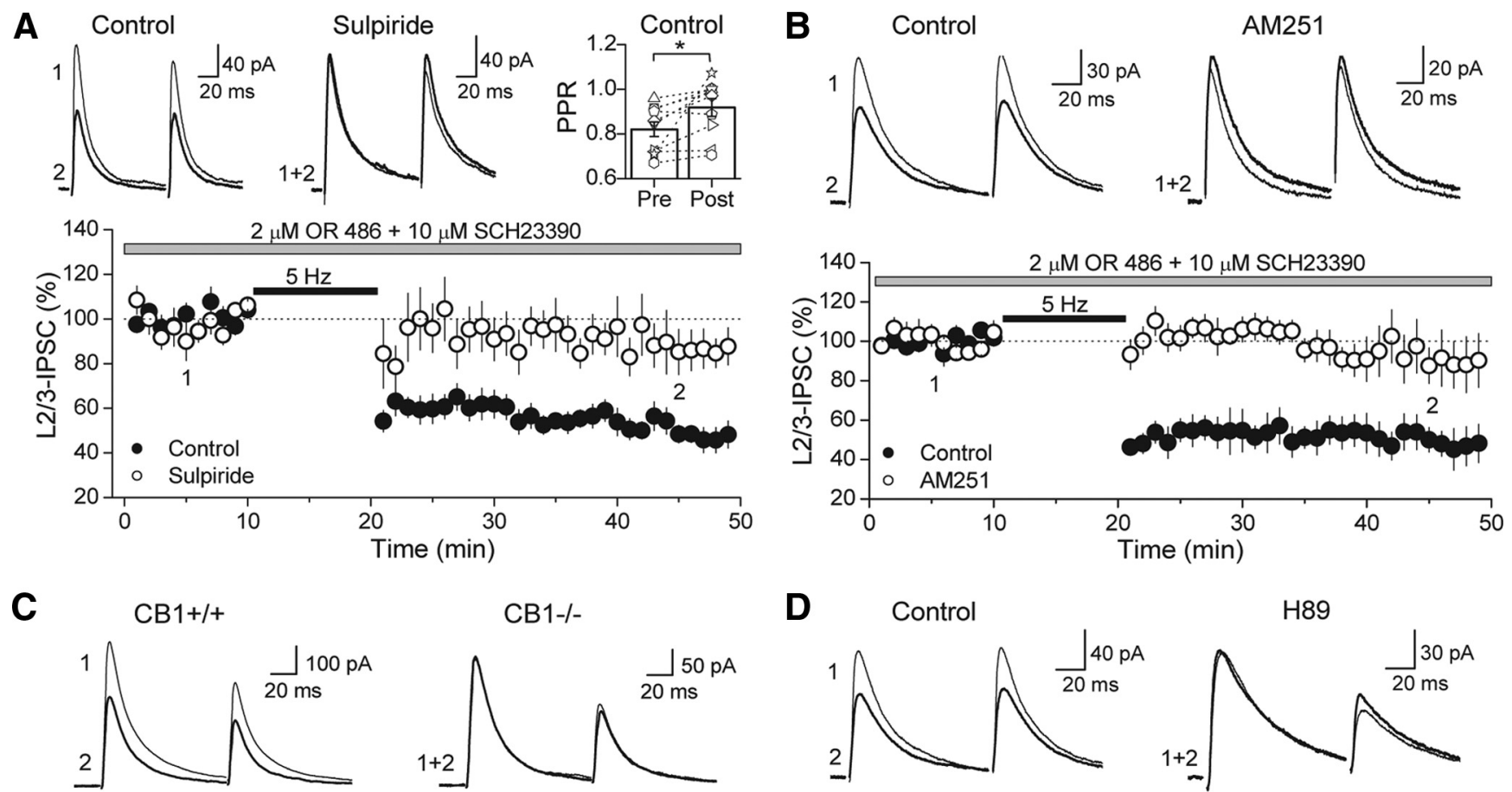

D Control

H89
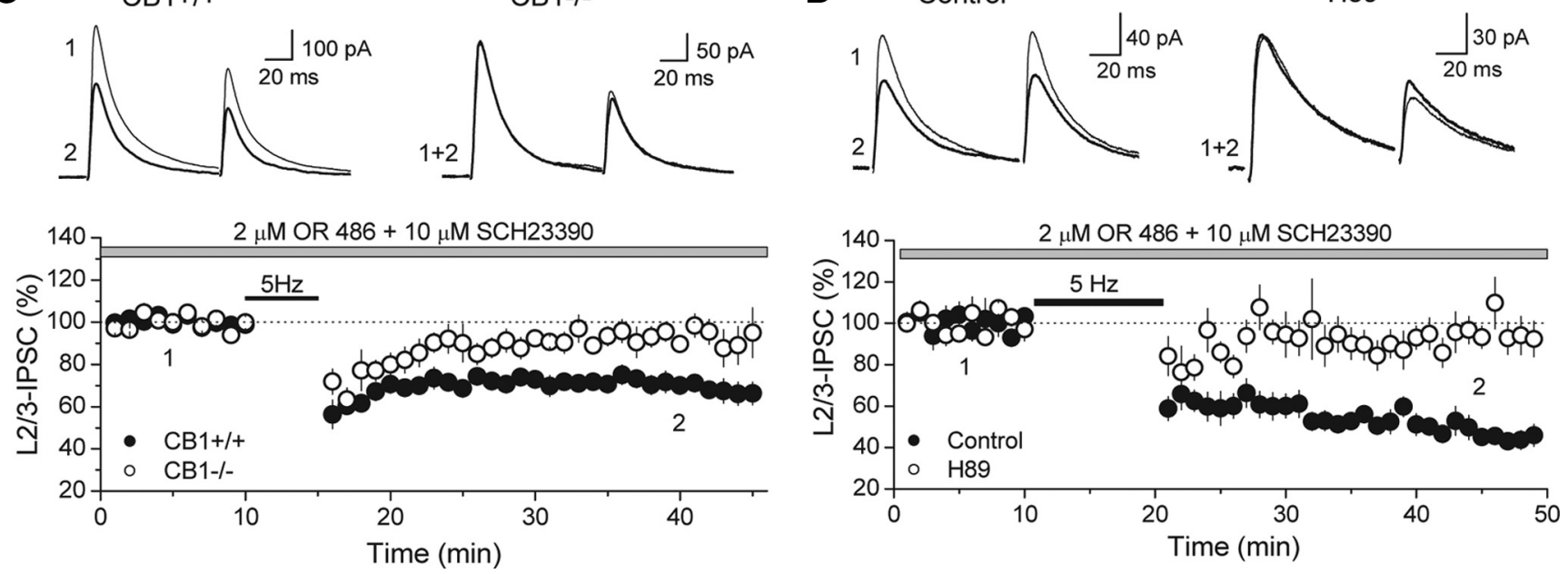

Figure 7. Increasing endogenous DA levels by inhibiting COMT also enables I-LTD. A, The $5 \mathrm{~Hz}$ stimulation in the presence of the COMT inhibitor OR 486 and the $\mathrm{D}_{1}$ R antagonist SCH23390 elicited I-LTD (black circles) that was sensitive to $D_{2}$ R antagonist sulpiride (white circles). Top left, Representative average traces from single experiments obtained at the time points indicated. Top right, Plot of PPR before and after delivery of $5 \mathrm{~Hz}$ train, showing a change in PPR. $\boldsymbol{B}$, This I-LTD (black circles) was also sensitive to the $\mathrm{CB}_{1}$ R antagonist AM 251 (white circles). Top, Representative average traces from single experiments obtained at time points indicated. $C$, In the wild-type mouse $\left(\mathrm{CB}_{1}^{+/+}\right)$, a weaker $5 \mathrm{~Hz}$ train (for $5 \mathrm{~min}$ ) triggers I-LTD in the presence of OR 486 and SCH23390. This I-LTD is not present in the $\mathrm{CB}_{1}$ knock-out littermates $\left(C B_{1}^{-/-}\right)$. Top, Representative average traces from single experiments obtained at the time points indicated. $D$, Time course of $I-L T D$ in the presence of OR 486 and SCH23390 in control (black circles) and in slices bath applied with H89 (white circles). Top, Representative average IPSC traces from single control and H89 block experiments in the rat PFC obtained at the time points indicated. L, Layer.

slice does. $\mathrm{D}_{2}$ Rs may signal via pathways other than PKA. In the striatum, activation of $\mathrm{D}_{2}$ Rs has been shown to lead to stimulation of phospholipase $C \beta$ isoforms and mobilization of intracellular calcium stores (Nishi et al., 1997; Hernandez-Lopez et al., 2000). However, two lines of evidence argue against a role for postsynaptic $\mathrm{D}_{2}$ Rs in facilitating I-LTD in the PFC. First, quinpirole suppression of IPSCs is completely insensitive to AM 251, indicating that $\mathrm{D}_{2} \mathrm{R}$ activation is insufficient to trigger eCB production in the PFC. Second, intracellular calcium rise is not required for I-LTD because loading the postsynaptic cell with BAPTA has no effect on plasticity. Because both $C_{1} R$ and $D_{2} R$ signaling can lead to inhibition of the PKA pathway, we postulate that coactivation of $\mathrm{CB}_{1}$ Rs and $\mathrm{D}_{2}$ Rs enables I-LTD in the PFC by cooperatively lowering PKA activity below a threshold level as supported by our observation of an enhancement of quinpirolemediated suppression by a submaximal concentration of WIN (Fig. 5A). A similar mechanism has been suggested recently for I-LTD in the VTA (Pan et al., 2008). The precise molecular PKA target underlying I-LTD remains to be identified.
It is widely accepted that DA modulates PFC function. Here, we show that DA may influence synaptic transmission and plasticity in the PFC by facilitating eCB signaling via presynaptic $\mathrm{D}_{2}$ Rs. Interestingly, our results using the COMT inhibitor OR 486 alone, in the absence of the $\mathrm{D}_{1} \mathrm{R}$ antagonist $\mathrm{SCH} 23390$ (supplemental Fig. S1, available at www.jneurosci.org as supplemental material), suggest that $\mathrm{D}_{1} \mathrm{R}$ activation may antagonize $\mathrm{D}_{2} \mathrm{R}$ facilitated I-LTD. This raises the question of whether DA likely facilitates I-LTD in the intact brain. However, some evidence suggests that $\mathrm{D}_{1}$ Rs and $\mathrm{D}_{2}$ Rs may be selectively activated in vivo. $\mathrm{D}_{2}$ Rs show comparatively higher affinity to DA than $\mathrm{D}_{1}$ Rs (Creese et al., 1983), and thus $\mathrm{D}_{2} \mathrm{R}$ activation may require lower concentrations of DA. It has been proposed, at least in the nucleus accumbens, that basal DA release continuously activate $\mathrm{D}_{2} \mathrm{Rs}$, whereas phasic DA release is needed to elevate DA levels enough to stimulate $D_{1}$ Rs (Grace, 1991). Moreover, tonic versus phasic DA transmission can be differentially evoked by distinct sets of afferents to DA neurons (Goto and Grace, 2005). It is possible that $\mathrm{D}_{2}$ Rs may be preferentially activated during tonic 
DA release conditions in the PFC as well, making GABAergic synapses primed for eCB signaling and I-LTD.

It is unclear how activation of $\mathrm{D}_{1}$ Rs opposes PFC I-LTD in our experiments; $D_{1}$ Rs may directly antagonize downstream $D_{2} R /$ $\mathrm{CB}_{1} \mathrm{R}$ signaling in the GABAergic terminal and/or mediate I-LTP at the same or different GABAergic synapse. We have shown with EM that a high proportion of presynaptic $\mathrm{D}_{2}$ Rs are colocalized with $\mathrm{CB}_{1}$ Rs (Fig. 1), but the extent of overlap between presynaptic $D_{1}$ Rs and $C B_{1}$ Rs remains unknown. Furthermore, given the high expression of postsynaptic $\mathrm{D}_{1} \mathrm{Rs}$ in the PFC (Ariano and Sibley, 1994; Smiley et al., 1994; Lidow et al., 2003), it is possible that these receptors mask I-LTD by mediating a potentiation of GABAergic transmission via an increase in number or conductance of $\mathrm{GABA}_{\mathrm{A}}$ receptors as has been shown for $\mathrm{D}_{1} \mathrm{R}$ and AMPAR (Sun et al., 2005).

In the PFC, eCBs have been shown to depress excitatory transmission (Lafourcade et al., 2007), and we now demonstrate that inhibitory transmission is also under eCB regulation. What, then, is the overall effect of eCBs on the balance of excitation and inhibition in the PFC and how is PFC output modulated? The answers to these questions may lie in the differential induction of E-LTD and I-LTD. It is interesting to note that eCB-mediated E-LTD in the PFC can be triggered by a slightly stronger synaptic stimulation train (e.g., 10 vs $5 \mathrm{~Hz}$ ) and does not require DA transmission. Furthermore, postsynaptic calcium rise is necessary for E-LTD but not I-LTD, suggesting that multiple mechanisms underlying eCB production may exist. Future studies will be needed to examine whether DA can modulate this form of E-LTD. Interestingly, a form of E-LTD, induced by brief highfrequency $(50 \mathrm{~Hz})$ stimulation, has been described previously in the PFC to depend on DA (Otani et al., 1998); the involvement of $\mathrm{eCB}$ signaling in this E-LTD is yet to be determined. Another provocative question is whether synaptic activity can simultaneously trigger both eCB-mediated E-LTD and I-LTD. If so, it will be important to assess changes in the firing properties of the output layer 5 pyramidal cells in PFC under conditions of intact excitation and inhibition.

In humans, cannabis consumption has dramatic effects on PFC-mediated function and can trigger schizophrenia-like states in normal individuals, exacerbate psychotic symptoms in schizophrenic patients, and increase the risk of developing schizophrenia in predisposed individuals (Ujike and Morita, 2004; Koethe et al., 2009; Sewell et al., 2009). In addition, studies using $\mathrm{CB}_{1} \mathrm{R}$ deficient mice have revealed an important role of eCBs in the extinction of learned behaviors, such as fear (Marsicano et al., 2002; Varvel and Lichtman, 2002), which are partly mediated by the PFC (Morgan et al., 1993; Morrow et al., 1999). It is currently unknown how eCBs and cannabinoid agonists can lead to these effects. The involvement of DA in the central actions of cannabinoids has been suggested (van der Stelt and Di Marzo, 2003; Laviolette and Grace, 2006). Cannabinergic signaling may lead to DA release (Cadogan et al., 1997; van der Stelt and Di Marzo, 2003) and can modulate $\mathrm{D}_{2} \mathrm{R}$ agonist-induced behavior (Beltramo et al., 2000; Gorriti et al., 2005). Indeed, microdialysis measurements have revealed an increase of DA in the PFC after in vivo administration of the cannabinoid $\Delta(9)$-tetrahydrocannabinol (Pistis et al., 2002). Notably, a decrease of GABA in the PFC was also observed in this study. Given that an imbalance of excitatory and inhibitory transmission in the PFC has been proposed to contribute to schizophrenia (Lewis et al., 2005; Gonzalez-Burgos and Lewis, 2008), these changes in neurotransmitter levels provide insight into how schizophrenic symptoms may emerge after cannabis consumption. We propose that a synergic interaction be- tween DA and eCB function at the synaptic level in the PFC (i.e., to trigger I-LTD) may play a role in schizophrenia in predisposed cannabis users.

\section{References}

Ariano MA, Sibley DR (1994) Dopamine receptor distribution in the rat CNS: elucidation using anti-peptide antisera directed against D1A and D3 subtypes. Brain Res 649:95-110.

Auclair N, Otani S, Soubrie P, Crepel F (2000) Cannabinoids modulate synaptic strength and plasticity at glutamatergic synapses of rat prefrontal cortex pyramidal neurons. J Neurophysiol 83:3287-3293.

Azad SC, Monory K, Marsicano G, Cravatt BF, Lutz B, Zieglgänsberger W, Rammes G (2004) Circuitry for associative plasticity in the amygdala involves endocannabinoid signaling. J Neurosci 24:9953-9961.

Beltramo M, de Fonseca FR, Navarro M, Calignano A, Gorriti MA, Grammatikopoulos G, Sadile AG, Giuffrida A, Piomelli D (2000) Reversal of dopamine $\mathrm{D}_{2}$ receptor responses by an anandamide transport inhibitor. J Neurosci 20:3401-3407.

Bodor AL, Katona I, Nyíri G, Mackie K, Ledent C, Hájos N, Freund TF (2005) Endocannabinoid signaling in rat somatosensory cortex: laminar differences and involvement of specific interneuron types. J Neurosci 25:6845-6856.

Cadogan AK, Alexander SP, Boyd EA, Kendall DA (1997) Influence of cannabinoids on electrically evoked dopamine release and cyclic AMP generation in the rat striatum. J Neurochem 69:1131-1137.

Cepeda C, Buchwald NA, Levine MS (1993) Neuromodulatory actions of dopamine in the neostriatum are dependent upon the excitatory amino acid receptor subtypes activated. Proc Natl Acad Sci U S A 90:9576-9580.

Chevaleyre V, Castillo PE (2003) Heterosynaptic LTD of hippocampal GABAergic synapses: a novel role of endocannabinoids in regulating excitability. Neuron 38:461-472.

Chevaleyre V, Takahashi KA, Castillo PE (2006) Endocannabinoidmediated synaptic plasticity in the CNS. Annu Rev Neurosci 29:37-76.

Chevaleyre V, Heifets BD, Kaeser PS, Südhof TC, Purpura DP, Castillo PE (2007) Endocannabinoid-mediated long-term plasticity requires cAMP/ PKA signaling and RIM1alpha. Neuron 54:801-812.

Creese I, Sibley DR, Hamblin MW, Leff SE (1983) The classification of dopamine receptors: relationship to radioligand binding. Annu Rev Neurosci 6:43-71.

Defagot MC, Villar MJ, Antonelli MC (2002) Differential localization of metabotropic glutamate receptors during postnatal development. Dev Neurosci 24:272-282.

Fadda F, Gessa GL, Marcou M, Mosca E, Rossetti Z (1984) Evidence for dopamine autoreceptors in mesocortical dopamine neurons. Brain Res 293:67-72.

Galarreta M, Erdélyi F, Szabó G, Hestrin S (2008) Cannabinoid sensitivity and synaptic properties of 2 GABAergic networks in the neocortex. Cereb Cortex 18:2296-2305.

Giuffrida A, Parsons LH, Kerr TM, Rodríguez de Fonseca F, Navarro M, Piomelli D (1999) Dopamine activation of endogenous cannabinoid signaling in dorsal striatum. Nat Neurosci 2:358-363.

Glass M, Felder CC (1997) Concurrent stimulation of cannabinoid CB $_{1}$ and dopamine $\mathrm{D}_{2}$ receptors augments cAMP accumulation in striatal neurons: evidence for a $G$ s linkage to the $\mathrm{CB}_{1}$ receptor. J Neurosci 17:5327-5333.

Goldman-Rakic PS (1998) The cortical dopamine system: role in memory and cognition. Adv Pharmacol 42:707-711.

Gonzalez-Burgos G, Lewis DA (2008) GABA neurons and the mechanisms of network oscillations: implications for understanding cortical dysfunction in schizophrenia. Schizophr Bull 34:944-961.

Gorelova NA, Yang CR (2000) Dopamine D1/D5 receptor activation modulates a persistent sodium current in rat prefrontal cortical neurons in vitro. J Neurophysiol 84:75-87.

Gorriti MA, Ferrer B, del Arco I, Bermúdez-Silva FJ, de Diego Y, Fernandez-Espejo E, Navarro M, Rodríguez de Fonseca F (2005) Acute delta9-tetrahydrocannabinol exposure facilitates quinpirole-induced hyperlocomotion. Pharmacol Biochem Behav 81:71-77.

Goto Y, Grace AA (2005) Dopaminergic modulation of limbic and cortical drive of nucleus accumbens in goal-directed behavior. Nat Neurosci 8:805-812.

Grace AA (1991) Phasic versus tonic dopamine release and the modulation 
of dopamine system responsivity: a hypothesis for the etiology of schizophrenia. Neuroscience 41:1-24.

Greengard P (2001) The neurobiology of slow synaptic transmission. Science 294:1024-1030.

Grobin AC, Deutch AY (1998) Dopaminergic regulation of extracellular gamma-aminobutyric acid levels in the prefrontal cortex of the rat. J Pharmacol Exp Ther 285:350-357.

Heifets BD, Castillo PE (2009) Endocannabinoid signaling and long-term synaptic plasticity. Annu Rev Physiol 71:283-306.

Heifets BD, Chevaleyre V, Castillo PE (2008) Interneuron activity controls endocannabinoid-mediated presynaptic plasticity through calcineurin. Proc Natl Acad Sci U S A 105:10250-10255.

Hernandez-Lopez S, Tkatch T, Perez-Garci E, Galarraga E, Bargas J, Hamm $\mathrm{H}$, Surmeier DJ (2000) $\mathrm{D}_{2}$ dopamine receptors in striatal medium spiny neurons reduce L-type $\mathrm{Ca}^{2+}$ currents and excitability via a novel PLC $\beta 1-$ IP3-calcineurin-signaling cascade. J Neurosci 20:8987-8995.

Hill EL, Gallopin T, Férézou I, Cauli B, Rossier J, Schweitzer P, Lambolez B (2007) Functional CB1 receptors are broadly expressed in neocortical GABAergic and glutamatergic neurons. J Neurophysiol 97:2580-2589.

Howlett AC, Breivogel CS, Childers SR, Deadwyler SA, Hampson RE, Porrino LJ (2004) Cannabinoid physiology and pharmacology: 30 years of progress. Neuropharmacology 47 [Suppl 1]:345-358.

Iversen SD, Iversen LL (2007) Dopamine: 50 years in perspective. Trends Neurosci 30:188-193.

Kano M, Ohno-Shosaku T, Hashimotodani Y, Uchigashima M, Watanabe M (2009) Endocannabinoid-mediated control of synaptic transmission. Physiol Rev 89:309-380.

Karoum F, Chrapusta SJ, Egan MF (1994) 3-Methoxytyramine is the major metabolite of released dopamine in the rat frontal cortex: reassessment of the effects of antipsychotics on the dynamics of dopamine release and metabolism in the frontal cortex, nucleus accumbens, and striatum by a simple two pool model. J Neurochem 63:972-979.

Kearn CS, Blake-Palmer K, Daniel E, Mackie K, Glass M (2005) Concurrent stimulation of cannabinoid CB1 and dopamine D2 receptors enhances heterodimer formation: a mechanism for receptor cross-talk? Mol Pharmacol 67:1697-1704.

Koethe D, Hoyer C, Leweke FM (2009) The endocannabinoid system as a target for modelling psychosis. Psychopharmacology (Berl) 206:551-561.

Kreitzer AC, Malenka RC (2005) Dopamine modulation of state-dependent endocannabinoid release and long-term depression in the striatum. J Neurosci 25:10537-10545.

Kreitzer AC, Malenka RC (2007) Endocannabinoid-mediated rescue of striatal LTD and motor deficits in Parkinson's disease models. Nature 445:643-647.

Lafourcade M, Elezgarai I, Mato S, Bakiri Y, Grandes P, Manzoni OJ (2007) Molecular components and functions of the endocannabinoid system in mouse prefrontal cortex. PLoS ONE 2:e709.

Laviolette SR, Grace AA (2006) The roles of cannabinoid and dopamine receptor systems in neural emotional learning circuits: implications for schizophrenia and addiction. Cell Mol Life Sci 63:1597-1613.

Lei W, Jiao Y, Del Mar N, Reiner A (2004) Evidence for differential cortical input to direct pathway versus indirect pathway striatal projection neurons in rats. J Neurosci 24:8289-8299.

Le Moal M, Simon H (1991) Mesocorticolimbic dopaminergic network: functional and regulatory roles. Physiol Rev 71:155-234.

Lewis DA, Hashimoto T, Volk DW (2005) Cortical inhibitory neurons and schizophrenia. Nat Rev Neurosci 6:312-324.

Lidow MS, Koh PO, Arnsten AF (2003) D1 dopamine receptors in the mouse prefrontal cortex: immunocytochemical and cognitive neuropharmacological analyses. Synapse 47:101-108.

Lovinger DM (2008) Presynaptic modulation by endocannabinoids. Handb Exp Pharmacol 184:435-477.

Marcellino D, Carriba P, Filip M, Borgkvist A, Frankowska M, Bellido I, Tanganelli S, Müller CE, Fisone G, Lluis C, Agnati LF, Franco R, Fuxe K (2008) Antagonistic cannabinoid CB1/dopamine D2 receptor interactions in striatal CB1/D2 heteromers. A combined neurochemical and behavioral analysis. Neuropharmacology 54:815-823.

Marsicano G, Wotjak CT, Azad SC, Bisogno T, Rammes G, Cascio MG, Hermann H, Tang J, Hofmann C, Zieglgänsberger W, Di Marzo V, Lutz B (2002) The endogenous cannabinoid system controls extinction of aversive memories. Nature 418:530-534.

Matsumoto M, Weickert CS, Akil M, Lipska BK, Hyde TM, Herman MM,
Kleinman JE, Weinberger DR (2003) Catechol O-methyltransferase mRNA expression in human and rat brain: evidence for a role in cortical neuronal function. Neuroscience 116:127-137.

Melis M, Pistis M, Perra S, Muntoni AL, Pillolla G, Gessa GL (2004) Endocannabinoids mediate presynaptic inhibition of glutamatergic transmission in rat ventral tegmental area dopamine neurons through activation of $\mathrm{CB}_{1}$ receptors. J Neurosci 24:53-62.

Mizuno T, Schmauss C, Rayport S (2007) Distinct roles of presynaptic dopamine receptors in the differential modulation of the intrinsic synapses of medium-spiny neurons in the nucleus accumbens. BMC Neurosci 8:8.

Morgan MA, Romanski LM, LeDoux JE (1993) Extinction of emotional learning: contribution of medial prefrontal cortex. Neurosci Lett 163:109-113.

Morrow BA, Elsworth JD, Inglis FM, Roth RH (1999) An antisense oligonucleotide reverses the footshock-induced expression of fos in the rat medial prefrontal cortex and the subsequent expression of conditioned fear-induced immobility. J Neurosci 19:5666-5673.

Neve KA, Seamans JK, Trantham-Davidson H (2004) Dopamine receptor signaling. J Recept Signal Transduct Res 24:165-205.

Nishi A, Snyder GL, Greengard P (1997) Bidirectional regulation of DARPP-32 phosphorylation by dopamine. J Neurosci 17:8147-8155.

Otani S, Blond O, Desce JM, Crépel F (1998) Dopamine facilitates longterm depression of glutamatergic transmission in rat prefrontal cortex. Neuroscience 85:669-676.

Pan B, Hillard CJ, Liu QS (2008) $\mathrm{D}_{2}$ dopamine receptor activation facilitates endocannabinoid-mediated long-term synaptic depression of GABAergic synaptic transmission in midbrain dopamine neurons via cAMP-protein kinase A signaling. J Neurosci 28:14018-14030.

Pedarzani P, Storm JF (1993) PKA mediates the effects of monoamine transmitters on the $\mathrm{K}^{+}$current underlying the slow spike frequency adaptation in hippocampal neurons. Neuron 11:1023-1035.

Pickel VM, Chan J, Kearn CS, Mackie K (2006) Targeting dopamine D2 and cannabinoid-1 (CB1) receptors in rat nucleus accumbens. J Comp Neurol 495:299-313.

Pistis M, Ferraro L, Pira L, Flore G, Tanganelli S, Gessa GL, Devoto P (2002) Delta(9)-tetrahydrocannabinol decreases extracellular GABA and increases extracellular glutamate and dopamine levels in the rat prefrontal cortex: an in vivo microdialysis study. Brain Res 948:155-158.

Rétaux S, Besson MJ, Penit-Soria J (1991) Opposing effects of dopamine D2 receptor stimulation on the spontaneous and the electrically evoked release of $\left[{ }^{3} \mathrm{H}\right] \mathrm{GABA}$ on rat prefrontal cortex slices. Neuroscience 42:61-71.

Seamans JK, Yang CR (2004) The principal features and mechanisms of dopamine modulation in the prefrontal cortex. Prog Neurobiol 74:1-58.

Seamans JK, Gorelova N, Durstewitz D, Yang CR (2001) Bidirectional dopamine modulation of GABAergic inhibition in prefrontal cortical pyramidal neurons. J Neurosci 21:3628-3638.

Sewell RA, Ranganathan M, D’Souza DC (2009) Cannabinoids and psychosis. Int Rev Psychiatry 21:152-162.

Shen W, Flajolet M, Greengard P, Surmeier DJ (2008) Dichotomous dopaminergic control of striatal synaptic plasticity. Science 321:848-851.

Smiley JF, Levey AI, Ciliax BJ, Goldman-Rakic PS (1994) D1 dopamine receptor immunoreactivity in human and monkey cerebral cortex: predominant and extrasynaptic localization in dendritic spines. Proc Natl Acad Sci U S A 91:5720-5724.

Sun X, Zhao Y, Wolf ME (2005) Dopamine receptor stimulation modulates AMPA receptor synaptic insertion in prefrontal cortex neurons. J Neurosci 25:7342-7351.

Takahashi KA, Castillo PE (2006) The CB1 cannabinoid receptor mediates glutamatergic synaptic suppression in the hippocampus. Neuroscience 139:795-802.

Takahashi KA, Linden DJ (2000) Cannabinoid receptor modulation of synapses received by cerebellar Purkinje cells. J Neurophysiol 83:1167-1180.

Trantham-Davidson H, Neely LC, Lavin A, Seamans JK (2004) Mechanisms underlying differential $D_{1}$ versus $D_{2}$ dopamine receptor regulation of inhibition in prefrontal cortex. J Neurosci 24:10652-10659.

Trettel J, Levine ES (2002) Cannabinoids depress inhibitory synaptic inputs received by layer $2 / 3$ pyramidal neurons of the neocortex. J Neurophysiol 88:534-539.

Tseng KY, O’Donnell P (2004) Dopamine-glutamate interactions controlling prefrontal cortical pyramidal cell excitability involve multiple signaling mechanisms. J Neurosci 24:5131-5139. 
Tseng KY, O’Donnell P (2007) D2 dopamine receptors recruit a GABA component for their attenuation of excitatory synaptic transmission in the adult rat prefrontal cortex. Synapse 61:843-850.

Ujike H, Morita Y (2004) New perspectives in the studies on endocannabinoid and cannabis: cannabinoid receptors and schizophrenia. J Pharmacol Sci 96:376-381.

van der Stelt M, Di Marzo V (2003) The endocannabinoid system in the basal ganglia and in the mesolimbic reward system: implications for neurological and psychiatric disorders. Eur J Pharmacol 480:133-150.

Varvel SA, Lichtman AH (2002) Evaluation of CB1 receptor knockout mice in the Morris water maze. J Pharmacol Exp Ther 301:915-924.

Vaughan CW, McGregor IS, Christie MJ (1999) Cannabinoid receptor activation inhibits GABAergic neurotransmission in rostral ventromedial medulla neurons in vitro. Br J Pharmacol 127:935-940.

Wang H, Pickel VM (2002) Dopamine D2 receptors are present in prefron- tal cortical afferents and their targets in patches of the rat caudateputamen nucleus. J Comp Neurol 442:392-404.

Xu TX, Sotnikova TD, Liang C, Zhang J, Jung JU, Spealman RD, Gainetdinov RR, Yao WD (2009) Hyperdopaminergic tone erodes prefrontal longterm potential via a $\mathrm{D}_{2}$ receptor-operated protein phosphatase gate. J Neurosci 29:14086-14099.

Yavich L, Forsberg MM, Karayiorgou M, Gogos JA, Männistö PT (2007) Site-specific role of catechol-O-methyltransferase in dopamine overflow within prefrontal cortex and dorsal striatum. J Neurosci 27:10196-10209.

Yin HH, Lovinger DM (2006) Frequency-specific and D2 receptormediated inhibition of glutamate release by retrograde endocannabinoid signaling. Proc Natl Acad Sci U S A 103:8251-8256.

Zimmer A, Zimmer AM, Hohmann AG, Herkenham M, Bonner TI (1999) Increased mortality, hypoactivity, and hypoalgesia in cannabinoid CB1 receptor knockout mice. Proc Natl Acad Sci U S A 96:5780-5785. 